\title{
Soft Ticks as Pathogen Vectors: Distribution, Surveillance and Control
}

\author{
Raúl Manzano-Román', Verónica Díaz-Martín", \\ José de la Fuente ${ }^{2,3}$ and Ricardo Pérez-Sánchez ${ }^{1}$ \\ ${ }^{1}$ Instituto de Recursos Naturales y Agrobiología de Salamanca (IRNASA-CSIC) \\ 2Instituto de Investigación en Recursos Cinegéticos IREC (CSIC-UCLM-JCCM) \\ ${ }^{3}$ Veterinary Pathobiology Department, Oklahoma State University, Stillwater \\ 1,2Spain \\ ${ }^{3} U S A$
}

\section{Introduction}

Ticks are highly specialized obligate haematophagous ectoparasites of mammals, birds and reptiles. Ticks are distributed worldwide and are of enormous medical and veterinary relevance owing to the direct damage they cause to their hosts and, especially, because they are vectors of a large variety of human and animal pathogens. In fact, ticks are second to mosquitoes as vectors of human pathogens and the most important vectors of pathogens affecting cattle worldwide (Peter et al., 2005). In humans, tick infestations typically involve few specimens and the greatest risk for people bitten by a tick lies in infection due to a tickborne pathogen (Parola \& Raoul, 2001). Such pathogens are diverse and include viruses, bacteria, and protozoa (Jongejan \& Uilenberg, 2004; de la Fuente et al., 2008a). In animals, tick infestations are much more severe than in humans. Animals can be parasitized by hundreds or even thousands of ticks, which obviously multiplies the effect on the host, either by direct injuries or disease transmission. Direct injuries to animals can be very serious, especially in tropical climates, and are mainly observed in infestations with ixodid ticks but also in infestations with some argasid ticks as Ornithodoros lahorensis and $O$. savignyi (Hoogstraal, 1985). The most frequent of these direct forms of damage include: (i) tissue destruction caused by the tick mouth parts and by the local inflammatory reaction of host to tick saliva; (ii) loss of blood, which in massive infestations can cause acute anaemia; (iii) paralyses caused by salivary toxins, such as the holocyclotoxin from the Australian tick Ixodes holocyclus, a tick species that can paralyze and kill a young animal with only one female bite; (iv) toxicoses, such as the Sweating sickness caused by the African Hyalomma truncatum; in ruminants this disease elicits eczematous skin lesions, hyperexcretion of exudates and more than $75 \%$ mortality in young animals, and (v) immunosuppression, which renders animals more susceptible to pathogen transmission (Mans et al., 2008a). All these direct forms of damage together with tick-transmitted diseases (including Babesiosis, Theileriosis, Anaplasmosis and Cowdriosis) cause important economic losses to the livestock industry, mainly affecting tropical and subtropical countries, where ticks constitute one of the main difficulties for the development of the livestock breeding industry (Jongejan and Uilenberg, 2004; Rajput et al., 2006). 
Tick species can be grouped in two main families, the Argasidae or soft ticks, and the Ixodidae or hard ticks. A third tick family, Nuttalliellidae, only has one species, Nuttalliella namaqua. These three families share common basic properties that are modified distinctively inside each family according to their particular behaviour patterns and life-style (Hoogstraal, 1985).

The family Argasidae includes some 193 species, but their phylogeny and taxonomy is as yet controversial, the genus-level classification of the family Argasidae being much less settled than that of the Ixodidae (Estrada-Peña et al., 2010), and most species of Argasidae can be assigned to more than one genus. A discussion of these issues is out of the scope of this review and the reader is referred to recent papers addressing them (Nava et al., 2009a; Guglielmone et al., 2010).

Argasid ticks differ from ixodids in a range of morphological and biological characteristics. Typically, argasids do not possess a dorsal shield or scutum; their capitulum is less prominent and ventrally -instead anteriorly- located; their coxae are unarmed (without spurs), and their spiracular plates are small. In Argasidae, there are more than four developmental stages in the life cycle: egg, larva, several nymphal stages, and adult. Nymphs have from two to eight separate instars. The exact number of instars varies according to the species and its future sex when adult. It is also influenced by the individual's state of nutrition. Argasids tend to be endophilic/nidicolous parasites that colonize the nests and burrows of their hosts and feed when the host arrives. In contrast, ixodids are mostly exophilic ticks that actively seek hosts when the seasons are suitable, although examples of nidicolous ixodid ticks also exist, especially among species of the genus Ixodes.

Some soft tick species exhibit extremely rigid host specificity. However, it has been suggested that most soft ticks show indiscriminate host feeding and such apparent variation in host preference probably reflects microhabitat preference and host availability within the microhabitat (Vial, 2009). Most argasids are fast feeders, ingesting a relatively small amount of blood per meal and adult specimens can feed and reproduce repeatedly. Argasids are very resistant to starvation and can survive for several years without feeding (Sonenshine, 1992). This, and their diapause periods, affords them great flexibility in their developmental cycles (Vial, 2009).

Argasid distribution can be considered cosmopolitan since they can be found throughout the world with the exception of places showing extreme conditions, although specimens have been found in Sub-Antarctic biogeographical regions (Estrada-Peña et al., 2003). The distribution of each particular species is more limited, but it may be very extensive, depending on factors such as the adaptability of each particular species to new ecological environments, the dissemination of immature phases by migratory birds, and the ability of adult specimens to infest different host species. It is therefore possible that species that have never been identified on one continent can be imported from different continents, and that new species can be identified in different parts of the world, contributing to a geographic distribution of soft tick species in constant evolution. Changes in argasid distribution are more difficult to predict than those of ixodids and currently no distribution models have yet been published for them. However, investigations are in progress, suggesting that soft tick distribution modelling is also possible. This modelling is based on the natural niche concept and takes into account the influence of climatic factors and the particularities of soft ticks, including their nidicolous lifestyle, indiscriminate host feeding, and a flexible developmental cycle along diapause periods (Vial, 2009). In this context, the development of 
new methods for systematic soft tick surveillance, i.e. serological methods, would help to monitor soft tick occurrence and the prediction of their distribution and its evolution. Table 1 offers information about the known distribution of a number of argasid species grouped by biogeographical regions (Udvardy, 1975). It should be noted that this table does not aim to be exhaustive but simply illustrative and that it might contain unconfirmed reports and some controversial species names.

\begin{tabular}{|c|c|c|c|}
\hline Species & Localization & Hosts & References \\
\hline \multicolumn{4}{|l|}{ Paleartic region } \\
\hline Argas abdussalami & Pakistan & Birds & Ghosh et al. (2007) \\
\hline Argas arboreus & Israel & Cattle, birds & Belozerov et al. (2003) \\
\hline Argas assimilis & China & Livestock & Chen et al. (2010) \\
\hline Argas beijingensis & China & Livestock & Chen et al. (2010) \\
\hline Argas miniatus & Portugal & Poultry & Lisbôa et al. (2009), \\
\hline Argas japonicus & China, Japan & $\begin{array}{l}\text { Livestock, } \\
\text { poultry }\end{array}$ & $\begin{array}{l}\text { Chen et al. (2010), Yamaguti et } \\
\text { al. (1968) }\end{array}$ \\
\hline Argas persicus & $\begin{array}{l}\text { Spain, Italy, Iran, } \\
\text { Pakistan, China, } \\
\text { Russian Federation }\end{array}$ & $\begin{array}{l}\text { Birds, poultry, } \\
\text { livestock }\end{array}$ & $\begin{array}{l}\text { Cordero del Campillo et al. } \\
\text { (1994), Pantaleoni et al. (2010), } \\
\text { Ntiamoa-Baidu et al. (2004), } \\
\text { Keirans \& Durden (2001), } \\
\text { Ghosh et al. (2007), Chen et al. } \\
\text { (2010), Dikaev (1981) }\end{array}$ \\
\hline Argas polonicus & Poland & Birds & Siuda (1996) \\
\hline Argas pusillus & $\begin{array}{l}\text { Tadzhikistan, } \\
\text { Kyrgyzstan, } \\
\text { Turkmenistan } \\
\end{array}$ & Bats, humans & $\begin{array}{l}\text { Gavrilovskaya (2001), de la } \\
\text { Fuente et al. (2008a) }\end{array}$ \\
\hline Argas reflexus & $\begin{array}{l}\text { Poland, Italy, France, } \\
\text { Spain, Iran, Pakistan, } \\
\text { Russian Federation }\end{array}$ & Humans, birds & $\begin{array}{l}\text { Karbowiak \& Supergan (2007), } \\
\text { Poggiato (2008), Gilot \& Pautou } \\
\text { (1982), Cordero del Campillo } \\
\text { et al. (1994), Ntiamoa-Baidu et } \\
\text { al. (2004), Siuda (1996), Ghosh } \\
\text { et al. (2007), Dikaev (1981) }\end{array}$ \\
\hline Argas robertsi & China & Birds & Chen et al. (2010) \\
\hline Argas vespertilionis & \begin{tabular}{|l|} 
Sweden, Portugal, \\
Great Britain, \\
Germany, Pakistan, \\
Tadzhikistan, \\
Kyrgyzstan, \\
Turkmenistan, Russian \\
Federation \\
\end{tabular} & $\begin{array}{l}\text { Bats, humans, } \\
\text { livestock }\end{array}$ & $\begin{array}{l}\text { Jaenson et al. (1994), Caeiro } \\
\text { (1999), Hubbard et al. (1998), } \\
\text { Gavrilovskaya (2001), de la } \\
\text { Fuente et al. (2008a), Cornely } \\
\text { \& Schultz (1992), Ghosh et al. } \\
\text { (2007), Dikaev (1981) }\end{array}$ \\
\hline Argas vulgaris & $\begin{array}{l}\text { China, Russian } \\
\text { Federation }\end{array}$ & Livestock & Chen et al. (2010), Dikaev (1981) \\
\hline Carios capensis & $\begin{array}{l}\text { Great Britain, Croatia, } \\
\text { Spain, China, } \\
\text { Torishima Island, } \\
\text { Japan }\end{array}$ & Seabirds & $\begin{array}{l}\text { Converse et al. (1975), Reeves et } \\
\text { al. (2006), Ushijima et al. (2003), } \\
\text { Chen et al. (2010) }\end{array}$ \\
\hline
\end{tabular}




\begin{tabular}{|c|c|c|c|}
\hline Species & Localization & Hosts & References \\
\hline Carios pusillus & China & Livestock & Chen et al. (2010) \\
\hline Carios sinensis & China & Livestock & Chen et al. (2010) \\
\hline Carios vespertilionis & China & Livestock & Chen et al. (2010) \\
\hline $\begin{array}{l}\text { Ornithodoros } \\
\text { alactagalis }\end{array}$ & $\begin{array}{l}\text { Armenia, Azerbaijan, } \\
\text { Georgia, Iran, } \\
\text { Northern Caucasus, } \\
\text { Transcaucasia, Turkey }\end{array}$ & NR & Filippova (1966) \\
\hline \begin{tabular}{|l|} 
Ornithodoros \\
asperus
\end{tabular} & Caucasus, Iraq & $\begin{array}{l}\text { Humans, } \\
\text { rodents }\end{array}$ & $\begin{array}{l}\text { Assous and Wilamowski } \\
\text { (2009), Parola \& Raoult (2001) }\end{array}$ \\
\hline $\begin{array}{l}\text { Ornithodoros } \\
\text { coniceps }\end{array}$ & $\begin{array}{l}\text { Italy, France, Spain, } \\
\text { Israel, Jordan, Egypt, } \\
\text { Afghanistan, Ukraine, }\end{array}$ & Pigeons & $\begin{array}{l}\text { Hoogstraal et al. (1979), Khoury } \\
\text { et al. (2011), Ghosh et al. } \\
(2007)\end{array}$ \\
\hline $\begin{array}{l}\text { Ornithodoros } \\
\text { erraticus }\end{array}$ & $\begin{array}{l}\text { Portugal, Spain, } \\
\text { Greece, Italy, Cyprus, } \\
\text { Algeria, Egypt, } \\
\text { Tunisia, Morocco, Iraq, } \\
\text { Iran }\end{array}$ & Humans, pigs & $\begin{array}{l}\text { Caeiro (1999), Oleaga-Pérez et } \\
\text { al (1990), Parola \& Raoult } \\
\text { (2001), EFSA (2010a) }\end{array}$ \\
\hline $\begin{array}{l}\text { Ornithodoros } \\
\text { lahorensis }\end{array}$ & $\begin{array}{l}\text { Armenia, Kazakhstan, } \\
\text { Russian Federation, } \\
\text { Kosovo, Syria, Turkey, } \\
\text { Iran, China }\end{array}$ & Cattle & $\begin{array}{l}\text { Moemenbellah-Fard et al (2009), } \\
\text { Ahmed et al. (2007), Chen et al. } \\
\text { (2010), Ghosh et al. (2007), } \\
\text { Aydin \& Bakirci (2007), EFSA } \\
\text { (2010c), Dikaev (1981) }\end{array}$ \\
\hline \begin{tabular}{|l|} 
Ornithodoros \\
maritimus
\end{tabular} & Portugal, Italy & Seabirds & Caeiro (1999), Manilla (1990) \\
\hline $\begin{array}{l}\text { Ornithodoros } \\
\text { pavlovsky }\end{array}$ & $\begin{array}{l}\text { Kazakhstan, Kirghizia, } \\
\text { Tajikistan, } \\
\text { Turkmenistan, } \\
\text { Uzbekistan }\end{array}$ & Mammals & Filippova (1966) \\
\hline $\begin{array}{l}\text { Ornithodoros } \\
\text { savignyi }\end{array}$ & Egypt & $\begin{array}{l}\text { Camel, sheep, } \\
\text { goat, cow, } \\
\text { buffalo }\end{array}$ & Helmy (2000) \\
\hline Ornithodoros sonrai & $\begin{array}{l}\text { Morocco, Libya, Egypt, } \\
\text { Turkey, Iran }\end{array}$ & $\begin{array}{l}\text { Domestic and } \\
\text { sylvatic pigs }\end{array}$ & Vial et al. (2006), Vial (2009) \\
\hline \begin{tabular}{|l|} 
Ornithodoros \\
tartakowskyi
\end{tabular} & $\begin{array}{l}\text { Iran, central Asia, } \\
\text { China }\end{array}$ & Humans & $\begin{array}{l}\text { Parola \& Raoult (2001), } \\
\text { Chen et al. (2010) }\end{array}$ \\
\hline $\begin{array}{l}\text { Ornithodoros } \\
\text { tholozani }\end{array}$ & $\begin{array}{l}\text { Cyprus, Daghestan, } \\
\text { Egypt, Iraq, Iran, } \\
\text { China, Israel, Jordan, } \\
\text { Kazakhstan, } \\
\text { Kyrgyzstan, Lebanon, } \\
\text { Libya, Syria, Turkey, } \\
\text { Ukraine, USSR }\end{array}$ & $\begin{array}{l}\text { Humans, } \\
\text { livestock }\end{array}$ & $\begin{array}{l}\text { Moemenbellah-Fard et al. (2009), } \\
\text { Assous et al. (2009), } \\
\text { Chen et al. (2010) }\end{array}$ \\
\hline $\begin{array}{l}\text { Ornithodoros } \\
\text { verrucosus }\end{array}$ & $\begin{array}{l}\text { Armenia, Georgia, } \\
\text { Russian Federation }\end{array}$ & NR & $\begin{array}{l}\text { Maruashvili (1965), } \\
\text { Gugushvili (1972), Dikaev } \\
\text { (1981) }\end{array}$ \\
\hline
\end{tabular}




\begin{tabular}{|c|c|c|c|}
\hline Species & Localization & Hosts & References \\
\hline \multicolumn{4}{|l|}{ Afrotropical region } \\
\hline Argas africolumbae & \begin{tabular}{|l|} 
Kenya, Tanzania, \\
South and South-West \\
Africa
\end{tabular} & Birds & Hoogstraal et al. (1977) \\
\hline Argas arboreus & South Africa & Cattle, birds & Mumcuoglu et al. (2005) \\
\hline Argas persicus & Ghana & Poultry & $\begin{array}{l}\text { Ntiamoa-Baidu et al. (2004), } \\
\text { Jongejan \& Uilenberg (2004) }\end{array}$ \\
\hline Argas reflexus & Ghana & $\begin{array}{l}\text { Humans, } \\
\text { poultry }\end{array}$ & $\begin{array}{l}\text { Ntiamoa-Baidu et al. (2004), } \\
\text { Siuda (1996), Jongejan \& } \\
\text { Uilenberg (2004) }\end{array}$ \\
\hline Argas walkerae & South Africa & Poultry & Nyangiwe et al. (2008) \\
\hline Argas vespertilionis & Ghana & Bats & Ntiamoa-Baidu et al. (2004) \\
\hline Carios capensis & Indic ocean islands & Seabirds & Converse et al. (1975) \\
\hline \begin{tabular}{|l|} 
Ornithodoros \\
compactus
\end{tabular} & South Africa & Tortoises & Horak et al. (2006) \\
\hline $\begin{array}{l}\text { Ornithodoros } \\
\text { coniceps }\end{array}$ & Kenya & Pigeons & Hoogstraal et al. (1979) \\
\hline $\begin{array}{l}\text { Ornithodoros } \\
\text { coriaceus }\end{array}$ & Africa & $\begin{array}{l}\text { Domestic and } \\
\text { sylvatic pigs }\end{array}$ & $\begin{array}{l}\text { Labuda \& Nuttall (2004), de la } \\
\text { Fuente et al. (2008a) }\end{array}$ \\
\hline \begin{tabular}{|l|} 
Ornithodoros \\
graingeri
\end{tabular} & Africa & Humans & Parola \& Raoult (2001) \\
\hline $\begin{array}{l}\text { Ornithodoros } \\
\text { moubata }\end{array}$ & $\begin{array}{l}\text { Central and South } \\
\text { Africa }\end{array}$ & $\begin{array}{l}\text { Humans, } \\
\text { domestic and } \\
\text { sylvatic pigs }\end{array}$ & $\begin{array}{l}\text { Ntiamoa-Baidu et al. (2004), } \\
\text { Parola \& Raoult (2001) }\end{array}$ \\
\hline $\begin{array}{l}\text { Ornithodoros } \\
\text { porcinus }\end{array}$ & $\begin{array}{l}\text { Southern and East } \\
\text { Africa }\end{array}$ & $\begin{array}{l}\text { Humans, } \\
\text { domestic and } \\
\text { sylvatic pigs }\end{array}$ & $\begin{array}{l}\text { Bastos et al. (2009), Mitani et } \\
\text { al. (2004) }\end{array}$ \\
\hline $\begin{array}{l}\text { Ornithodoros } \\
\text { savignyi }\end{array}$ & $\begin{array}{l}\text { Kenya, Central and } \\
\text { South Africa }\end{array}$ & $\begin{array}{l}\text { Livestock, } \\
\text { humans }\end{array}$ & $\begin{array}{l}\text { Walton (1951), Howell (1966), } \\
\text { Hoogstraal (1985) }\end{array}$ \\
\hline Ornithodoros sonrai & \begin{tabular}{|l|} 
Kenya, Mauritania, \\
Senegal, Mali, Gambia
\end{tabular} & $\begin{array}{l}\text { Domestic and } \\
\text { sylvatic pigs }\end{array}$ & Vial et al. (2006), Vial (2009) \\
\hline $\begin{array}{l}\text { Ornithodoros } \\
\text { turicata }\end{array}$ & Africa & $\begin{array}{l}\text { Domestic and } \\
\text { sylvatic pigs }\end{array}$ & $\begin{array}{l}\text { Labuda \& Nuttall (2004), de la } \\
\text { Fuente et al. (2008a) }\end{array}$ \\
\hline $\begin{array}{l}\text { Ornithodoros } \\
\text { zumpti }\end{array}$ & Africa & Humans & Rebaudet \& Parola (2006) \\
\hline \multicolumn{4}{|l|}{ Neartic region } \\
\hline Argas cooleyi & USA & Humans & Calisher et al. (1988) \\
\hline Argas monolakensis & Mono Lake (USA) & Humans & Schwan et al. (1992) \\
\hline Argas persicus & USA & Poultry & Keirans et al. (2001) \\
\hline Carios capensis & $\begin{array}{l}\text { Hawaii, South } \\
\text { Carolina, and Texas } \\
\text { (USA) }\end{array}$ & Seabirds & $\begin{array}{l}\text { Reeves et al. (2006), Rawlings } \\
\text { (1995) }\end{array}$ \\
\hline $\begin{array}{l}\text { Ornithodoros } \\
\text { coriaceus }\end{array}$ & $\begin{array}{l}\text { California, Oregon and } \\
\text { Nevada (USA) }\end{array}$ & Cattle & $\begin{array}{l}\text { Teglas et al. (2006), Failing et } \\
\text { al. (1972) }\end{array}$ \\
\hline
\end{tabular}




\begin{tabular}{|c|c|c|c|}
\hline Species & Localization & Hosts & References \\
\hline \begin{tabular}{|l|} 
Ornithodoros \\
hermsi
\end{tabular} & USA, Canada & Humans & \begin{tabular}{|l} 
Dana (2009), Schwan et al. \\
(2007), Parola \& Raoult (2001)
\end{tabular} \\
\hline Ornithodoros kelleyi & USA & Bats, humans & Cilek \& Knapp (1992) \\
\hline \begin{tabular}{|l|} 
Ornithodoros \\
parkeri
\end{tabular} & USA, Canada & Human & $\begin{array}{l}\text { Dana (2009), Dworkin et al. } \\
(2002)\end{array}$ \\
\hline \begin{tabular}{|l|} 
Ornithodoros \\
puertoricensis
\end{tabular} & USA & Reptiles & $\begin{array}{l}\text { Venzal et al. }(2006,2008), \\
\text { Bermúdez et al. }(2010)\end{array}$ \\
\hline Ornithodoros rossi & USA & Bats & Steinlein et al. (2001) \\
\hline Ornithodoros talaje & USA & $\begin{array}{l}\text { Rodents, } \\
\text { domestic } \\
\text { animals, } \\
\text { humans } \\
\end{array}$ & Parola \& Raoult (2001) \\
\hline $\begin{array}{l}\text { Ornithodoros } \\
\text { turicata }\end{array}$ & USA, Canada & $\begin{array}{l}\text { Humans, dogs, } \\
\text { tortoises }\end{array}$ & $\begin{array}{l}\text { Dana (2009), Dworkin et al. } \\
\text { (2008), Whitney et al. (2007), } \\
\text { Adeyeye et al. (1989) }\end{array}$ \\
\hline Otobius megnini & USA & Humans, cattle & Nava et al. $(2006,2009 b)$ \\
\hline \multicolumn{4}{|l|}{ Neotropical region } \\
\hline Antricola delacruzi & Brazil & Bats & Labruna et al. (2008) \\
\hline \begin{tabular}{|l} 
Antricola \\
guglielmonei
\end{tabular} & Brazil & Bats & Labruna et al. (2008) \\
\hline Argas dulus & Dominican Republic & Birds & Keirans et al. (1971) \\
\hline Argas keiransi & Chile & Birds & $\begin{array}{l}\text { Estrada-Peña et al. (2003, } \\
2006)\end{array}$ \\
\hline Argas persicus & Paraguay & $\begin{array}{l}\text { Poultry, birds, } \\
\text { livestock }\end{array}$ & Nava et al. (2007) \\
\hline Argas miniatus & Paraguay, Chile, Brazil & Pultry & $\begin{array}{l}\text { González-Acuña \& Guglielmone } \\
\text { (2005), Nava et al. (2007), } \\
\text { Ataliba et al. (2007) }\end{array}$ \\
\hline Argas monachus & Argentina, Paraguay & Birds & $\begin{array}{l}\text { Keirans et al. (1973), Nava et al. } \\
(2007)\end{array}$ \\
\hline Argas neghmei & Argentina, Chile & $\begin{array}{l}\text { Poultry, } \\
\text { humans }\end{array}$ & Di Iorio et al. (2010) \\
\hline Carios mimon & $\begin{array}{l}\text { Bolivia, Uruguay, } \\
\text { Brazil }\end{array}$ & Bats, humans & Barros-Battesti et al. (2011) \\
\hline $\begin{array}{l}\text { Nothoaspis } \\
\text { amazoniensis }\end{array}$ & Brazil & Bats & Nava et al. (2010) \\
\hline $\begin{array}{l}\text { Ornithodoros } \\
\text { rioplatensis }\end{array}$ & $\begin{array}{l}\text { Uruguay, Argentina, } \\
\text { Chile }\end{array}$ & NR & Venzal et al. (2008) \\
\hline $\begin{array}{l}\text { Ornithodoros } \\
\text { amblus }\end{array}$ & Peru, Chile & Birds & $\begin{array}{l}\text { Clifford et al. (1980), Need et al. } \\
(1991)\end{array}$ \\
\hline $\begin{array}{l}\text { Ornithodoros } \\
\text { brasiliensis }\end{array}$ & Brazil & Humans & Martins et al. (2011) \\
\hline $\begin{array}{l}\text { Ornithodoros } \\
\text { coriaceus }\end{array}$ & Mexico & Humans & Failing et al. (1972) \\
\hline
\end{tabular}




\begin{tabular}{|c|c|c|c|}
\hline Species & Localization & Hosts & References \\
\hline Ornithodoros hasei & Paraguay & NR & Nava et al. (2007) \\
\hline $\begin{array}{l}\text { Ornithodoros } \\
\text { hermsi }\end{array}$ & Mexico & Humans & $\begin{array}{l}\text { Dana (2009), Schwan et al. } \\
\text { (2007), Parola \& Raoult (2001) }\end{array}$ \\
\hline $\begin{array}{l}\text { Ornithodoros } \\
\text { marinkellei }\end{array}$ & $\begin{array}{l}\text { Colombia, Panama, } \\
\text { Venezuela, Guyana, } \\
\text { Brazil }\end{array}$ & Bats & Labruna et al. (2011) \\
\hline \begin{tabular}{|l|} 
Ornithodoros \\
parkeri
\end{tabular} & Mexico & Humans & $\begin{array}{l}\text { Dana (2009), Dworkin et al. } \\
(2002)\end{array}$ \\
\hline $\begin{array}{l}\text { Ornithodoros } \\
\text { puertoricensis }\end{array}$ & $\begin{array}{l}\text { México, Guatemala, } \\
\text { Nicaragua, Panama, } \\
\text { Colombia, Venezuela, } \\
\text { Paraguay , Jamaica, } \\
\text { Dominican Republic, } \\
\text { Puerto Rico, Haiti }\end{array}$ & Reptiles & $\begin{array}{l}\text { Nava et al. (2007), Venzal et al. } \\
(2006,2008), \text { Bermúdez et al. } \\
(2010) \text {, Endris et al. (1989) }\end{array}$ \\
\hline $\begin{array}{l}\text { Ornithodoros } \\
\text { rondoniensis }\end{array}$ & Brazil & Bats & Labruna et al. (2008) \\
\hline $\begin{array}{l}\text { Ornithodoros } \\
\text { rostratus }\end{array}$ & $\begin{array}{l}\text { Paraguay, Brazil, } \\
\text { Argentina }\end{array}$ & Reptiles & $\begin{array}{l}\text { Venzal et al. (2006), Martins et } \\
\text { al. (2011), Guglielmone et al. } \\
(2003)\end{array}$ \\
\hline Ornithodoros rudis & Paraguay & Humans & Parola \& Raoult (2001) \\
\hline $\begin{array}{l}\text { Ornithodoros } \\
\text { spheniscus }\end{array}$ & Chile & Penguins & $\begin{array}{l}\text { González-Acuña \& } \\
\text { Guglielmone (2005) }\end{array}$ \\
\hline Ornithodoros talaje & México, Brazil, Chile1 & $\begin{array}{l}\text { Rodents, } \\
\text { domestic } \\
\text { animals, } \\
\text { humans } \\
\end{array}$ & $\begin{array}{l}\text { Tizu et al. (1995), Parola \& } \\
\text { Raoult (2001), González-Acuña } \\
\text { \& Guglielmone (2005) }\end{array}$ \\
\hline $\begin{array}{l}\text { Ornithodoros } \\
\text { turicata }\end{array}$ & Mexico & Human & Dana (2009) \\
\hline $\begin{array}{l}\text { Ornithodoros } \\
\text { yunkeri }\end{array}$ & Galapagos Islands & Seabirds & Keirans et al. (1984) \\
\hline Otobius megnini & Argentina, Chile & Humans, cattle & Nava et al. $(2006,2009 b)$ \\
\hline \multicolumn{4}{|c|}{ Oriental region (Indomalayan) } \\
\hline Argas abdussalami $^{1}$ & India & Livestock & Ghosh et al. (2007) \\
\hline \begin{tabular}{|l|}
$\begin{array}{l}\text { Argas } \\
\text { gujaratensis } 1,2\end{array}$ \\
\end{tabular} & India & Bats & Ghosh et al. (2007) \\
\hline Argas hermanni & India & Birds & Ghosh et al. (2007) \\
\hline Argas hoogstraali 1 & India & $\begin{array}{l}\text { Bats, wild } \\
\text { mammals }\end{array}$ & Ghosh et al. (2007) \\
\hline Argas indicus ${ }^{1,2}$ & India & $\begin{array}{l}\text { Bats, wild } \\
\text { mammals }\end{array}$ & Ghosh et al. (2007) \\
\hline Argas japonicus & China, Korea & $\begin{array}{l}\text { Livestock, } \\
\text { poultry }\end{array}$ & $\begin{array}{l}\text { Chen et al. (2010), Yamaguti et } \\
\text { al. (1968) }\end{array}$ \\
\hline Argas persicus & India, Bangladesh & $\begin{array}{l}\text { Poultry, birds, } \\
\text { livestock }\end{array}$ & $\begin{array}{l}\text { Keirans et al. (2001), Ntiamoa- } \\
\text { Baidu et al. (2004), Ghosh et al. } \\
(2007)\end{array}$ \\
\hline
\end{tabular}




\begin{tabular}{|c|c|c|c|}
\hline Species & Localization & Hosts & References \\
\hline Argas robertsi & $\begin{array}{l}\text { Taiwan, Thailand, } \\
\text { India, Indonesia, Sri } \\
\text { Lanka }\end{array}$ & Birds & $\begin{array}{l}\text { Hoogstraal et al. (1975), } \\
\text { Ghosh et al. (2007) }\end{array}$ \\
\hline Argas soneshinei1,2 & India & Livestock & Ghosh et al. (2007) \\
\hline Argas vespertilionis & India & $\begin{array}{l}\text { Livestock, bats, } \\
\text { humans }\end{array}$ & $\begin{array}{l}\text { Gavrilovskaya (2001), Ghosh } \\
\text { et al. (2007), de la Fuente et al. } \\
(2008 a)\end{array}$ \\
\hline Argas wilsoni1,2 & India & Bats & Ghosh et al. (2007) \\
\hline Carios batuensis & Indonesia & Bats & Durden et al. (2008) \\
\hline $\begin{array}{l}\text { Carios } \\
\text { chiropterphila }{ }^{1,2}\end{array}$ & India & Bats & Ghosh et al. (2007) \\
\hline Carios faini ${ }^{1}$ & India & $\begin{array}{l}\text { Bats, wild } \\
\text { mammals }\end{array}$ & Ghosh et al. (2007) \\
\hline $\begin{array}{l}\text { Ornithodoros } \\
\text { coniceps }\end{array}$ & India & Pigeons & $\begin{array}{l}\text { Hoogstraal et al. (1979), Ghosh } \\
\text { et al. (2007) }\end{array}$ \\
\hline Ornithodoros crossi2 & India & Livestock & Ghosh et al. (2007) \\
\hline $\begin{array}{l}\text { Ornithodoros } \\
\text { lahorensis }\end{array}$ & India & Cattle & $\begin{array}{l}\text { Moemenbellah-Fard et al. } \\
\text { (2009), Ahmed et al. (2007), } \\
\text { Ghosh et al. (2007) }\end{array}$ \\
\hline $\begin{array}{l}\text { Ornithodoros } \\
\text { piriformis }{ }^{1}\end{array}$ & India & Bats & Ghosh et al. (2007) \\
\hline $\begin{array}{l}\text { Ornithodoros } \\
\text { savignyi }\end{array}$ & India & Livestock & Ghosh et al. (2007) \\
\hline $\begin{array}{l}\text { Ornithodoros } \\
\text { tholozani }\end{array}$ & India, Kashmir & Human & $\begin{array}{l}\text { Moemenbellah-Fard et al . } \\
(2009) \text {, Assous \& Wilamowski } \\
(2009)\end{array}$ \\
\hline Otobius megnini & India & $\begin{array}{l}\text { Humans, } \\
\text { cattle, dogs }\end{array}$ & $\begin{array}{l}\text { Nava et al. }(2006,2009 b), \\
\text { Ghosh et al. (2007) }\end{array}$ \\
\hline \multicolumn{4}{|l|}{ Australian } \\
\hline Argas persicus & Southern Australia & Poultry & Petney et al. (2004) \\
\hline Argas robertsi & Australia & Birds & Hoogstraal et al. (1975) \\
\hline Carios capensis & $\begin{array}{l}\text { Heron island, } \\
\text { Australia }\end{array}$ & Humans & Humphery-Smith et al. (1991) \\
\hline
\end{tabular}

Table 1. Soft tick distribution ordered by biogeographical regions (historical records). ${ }^{1} \mathrm{Need}$ confirmation; ${ }^{2}$ controversial name. NR, not reported.

\section{Pathogens and infectious diseases transmitted by soft ticks}

Ticks are among the most competent and versatile arthropod vectors of pathogens. Today, most emerging infectious diseases arise from zoonotic pathogens, and many of them are transmitted by arthropod vectors. Tick-borne infectious diseases are a growing and very serious world health problem and a major obstacle for animal health and production (Rajput et al., 2006). For example, in the United States Lyme disease is transmitted by Ixodes ticks and it has become the most common arthropod-borne infectious disease in that country (Díaz, 2009). In Europe, important pathogens transmitted by ticks are Borrelia spp., 
Anaplasma spp., Rickettsia spp., Babesia spp., Tick borne Encephalitis Virus (TBEV), and Crimean-Congo Haemorrhagic Fever Virus (CCHFV) (Heyman et al., 2010). In Africa, tickborne diseases and tick infestations are among the most commonly documented causes of morbidity (Phiri et al., 2010).

Regarding the pathogens transmitted by argasid ticks, they are mainly viruses together with a number of bacterial species, and they cause severe diseases in humans and animals. The currently recognized viral diseases transmitted by soft ticks are shown in Table 2. Among them, African swine fever (ASF) has received particular attention and will be used as a model in this review. The argasid-borne bacteria are almost exclusively borreliae, which cause relapsing fever in humans (Table 3). Other potential argasid-borne pathogens that have been transmitted experimentally are shown in Table 4 . Finally, most vector specimens also contain a range of non-pathogenic microorganisms that can also be transmitted to the host in the tick saliva, some of them also being included in Table 4.

\subsection{African swine fever virus}

The African swine fever virus (ASFV) belongs to the Asfarviridae family of arboviruses and represents the only known DNA arbovirus to date (Kleiboeker \& Scoles, 2001; Labuda \& Nuttall, 2008). It affects only porcine species and causes African swine fever (ASF), highly lethal to pigs, which is one of the most important viral diseases of swine included in the A list of the OIE (http:/ / www.oie.int/en/animal-health-in-the-world/oie-listed-diseases-2011/).

In nature ASFV circulates in two types of enzootic cycles -sylvatic and domestic- both of which involve porcine hosts and argasid ticks of the genus Ornithodoros, including $O$. moubata, O. porcinus, O. savignyi, and O. sonrai in Africa; members of the O. erraticus complex on the Iberian Peninsula, the trans-Caucasus countries and the Russian Federation, and $O$. coriaceus, O. turicata, O. parkeri and O. puertoricensis in North America and the Caribbean (Kleiboeker \& Scoles, 2001; Labuda \& Nuttall, 2008). The virus replicates in the tissues of these tick species and, depending on the species, can be transmitted transstadially, transovarially and sexually (EFSA panel, 2010c). Among the Old World species, transovarial, transstadial and sexual transmission of ASFV have been described in $O$. moubata; transstadial and sexual transmission have been demonstrated for $O$. erraticus (Endris \& Hess, 1994) and only transstadial transmission has been demonstrated for $O$. savignyi. Among the New World species, the transstadial transmission of ASFV has only been demonstrated for $O$. coriaceus and $O$. parkeri, and transovarial transmission has only been demonstrated for O. puertoricensis (Kleiboeker \& Scoles, 2001). Thus, it can be said that all Ornithodoros species investigated so far (i.e., those mentioned above) can become readily infected by ASF, and all of them, except O. parkeri (EFSA, 2010c), can also transmit the virus to pigs, thereby playing a potential role not only as reservoirs but also as active biological vectors of ASFV. Interestingly, in spite of evidence suggesting that $O$. puertoricensis could be an efficient vector for ASFV, the presence of this tick in Haiti and the Dominican Republic did not appear to complicate the eradication of ASF from those countries in 1978. This was probably due to a lack of contact between infected pigs and O. puertoricensis, since the Dominican Republic II strain of ASFV (one of the strains isolated from that epizootic outbreak) was shown to be capable of infecting and being transmitted by these ticks under experimental conditions (Kleiboeker \& Scoles, 2001). Other Ornithodoros species remain untested for ASFV infection and transmission and the possibility that they might play some kind of role in the epidemiology of ASF cannot be ruled out. 


\begin{tabular}{|c|c|c|}
\hline Soft tick species & Virus & References \\
\hline Argas robertsi & $\begin{array}{l}\text { Kao Shuan virus, Pathum Thani } \\
\text { virus, } \\
\text { Nyamanini virus, Lake Clarendon } \\
\text { virus }\end{array}$ & $\begin{array}{l}\text { Hoogstraal et al. (1975), } \\
\text { Hoogstraal (1985), Labuda \& } \\
\text { Nuttall (2008) }\end{array}$ \\
\hline Argas abdussalami & $\begin{array}{l}\text { Manawa virus, Bakau virus, } \\
\text { Uukuniemi virus }\end{array}$ & $\begin{array}{l}\text { Hoogstraal (1985), Labuda \& } \\
\text { Nuttall (2008) }\end{array}$ \\
\hline Argas africolumbae & Pretoria virus & Labuda \& Nuttall (2008) \\
\hline Argas arboreus & $\begin{array}{l}\text { West Nile virus, Quaranfil virus, } \\
\text { Nyamanini virus }\end{array}$ & $\begin{array}{l}\text { Hoogstraal (1985), Mumcuoglu } \\
\text { et al. (2005) }\end{array}$ \\
\hline Argas cooleyi & $\begin{array}{l}\text { Mono Lake virus, Sixgun virus, } \\
\text { Sapphire II virus, Sunday Canyon } \\
\text { virus }\end{array}$ & $\begin{array}{l}\text { Hoogstraal (1985), Calisher et } \\
\text { al. (1988), Vermeil et al. (1996), } \\
\text { Labuda \& Nuttall (2008), de la } \\
\text { Fuente et al. (2008a), }\end{array}$ \\
\hline Argas hermanni & \begin{tabular}{|l|} 
Chenuda virus, Abu Hammad \\
virus, \\
Royal Farm virus, West Nile virus, \\
Grand Arbaud virus, Nyamanini \\
virus, \\
Quaranfil virus
\end{tabular} & $\begin{array}{l}\text { Hoogstraal (1985), Labuda \& } \\
\text { Nuttall (2008) }\end{array}$ \\
\hline Argas monolakensis & Mono Lake Virus & $\begin{array}{l}\text { Schwan et al. (1992), Vermeil et } \\
\text { al. (1996), de la Fuente et al. } \\
\text { (2008a) }\end{array}$ \\
\hline Argas persicus & CCHF virus & Hoogstraal (1985) \\
\hline Argas pusillus & Issyk-Kul Fever virus & $\begin{array}{l}\text { Gavrilovskaya (2001), de la } \\
\text { Fuente et al. (2008a) }\end{array}$ \\
\hline Argas reflexus & $\begin{array}{l}\text { Uukuniemi virus, } \\
\text { CCHF virus }\end{array}$ & $\begin{array}{l}\text { Labuda \& Nuttall (2008), } \\
\text { Tahmasebi et al. (2010) }\end{array}$ \\
\hline Argas vespertilionis & $\begin{array}{l}\text { Issyk-Kul Fever virus, } \\
\text { Sokuluk virus }\end{array}$ & \begin{tabular}{|l|} 
Hoogstraal (1985), \\
Gavrilovskaya (2001), de la \\
Fuente et al. (2008a)
\end{tabular} \\
\hline Carios amblus & Mono lake virus & Labuda \& Nuttall (2008) \\
\hline Carios capensis & $\begin{array}{l}\text { Upolu virus, Nyaminini virus, } \\
\text { Quaranfil virus, Saumarez Reef } \\
\text { vírus, } \\
\text { Soldado vírus, Hughes virus }\end{array}$ & $\begin{array}{l}\text { Converse et al. (1975), } \\
\text { Hoogstraal (1985), Labuda \& } \\
\text { Nuttall }(2004,2008)\end{array}$ \\
\hline Carios maritimus & Chenuda virus, West Nile virus & Labuda \& Nuttall (2008) \\
\hline Carios spp. & Chobar Gorge virus & Labuda \& Nuttall (2008) \\
\hline $\begin{array}{l}\text { OME/CTVM21 O. } \\
\text { moubata cells }\end{array}$ & Karshi and Langat virus & Bell-Sakyi et al. (2009) \\
\hline Ornithodoros amblus & Huacho virus, Punta Salinas virus & Hoogstraal (1985) \\
\hline Ornithodoros coniceps & Baku virus & Hoogstraal et al. (1979) \\
\hline Ornithodoros coriaceus & ASFV $^{1}$, Bluetongue virus & $\begin{array}{l}\text { Groocock et al. (1980), Stott et } \\
\text { al. (1985), Kleiboeker et al. } \\
\text { (1998), Labuda \& Nuttall (2004), } \\
\text { de la Fuente et al. (2008a) }\end{array}$ \\
\hline Ornithodoros denmarki & $\begin{array}{l}\text { Soldado virus, Hughes virus, } \\
\text { Raza virus, Quaranfil group }\end{array}$ & $\begin{array}{l}\text { Labuda \& Nuttall (2004), de la } \\
\text { Fuente et al. (2008a) }\end{array}$ \\
\hline
\end{tabular}




\begin{tabular}{|c|c|c|}
\hline Soft tick species & Virus & References \\
\hline Ornithodoros erraticus & Qalyub virus (QYB), ASFV & $\begin{array}{l}\text { Miller et al. (1985), Labuda \& } \\
\text { Nuttall (2004, 2008), Basto et al. } \\
(2006) \text {, de la Fuente et al. } \\
\text { (2008a) }\end{array}$ \\
\hline Ornithodoros kohlsi & Matucare virus & Labuda \& Nuttall (2008) \\
\hline \begin{tabular}{|l|} 
Ornithodoros \\
lagophilus
\end{tabular} & Colorado tick fever virus & Sonenshine et al. (2002) \\
\hline $\begin{array}{l}\text { Ornithodoros } \\
\text { lahorensis }\end{array}$ & CCHF virus & $\begin{array}{l}\text { Hoogstraal (1985), Telmadarraiy } \\
\text { et al. (2010) }\end{array}$ \\
\hline \begin{tabular}{|l|} 
Ornithodoros \\
maritimus
\end{tabular} & Soldado virus & $\begin{array}{l}\text { Labuda \& Nuttall (2004), de la } \\
\text { Fuente et al. (2008a) }\end{array}$ \\
\hline Ornithodoros moubata & $\begin{array}{l}\text { ASFV, } \\
\text { West Nile virus, } \\
\text { HIV2,3 } \\
\text { Hepatitis B virus }^{1}\end{array}$ & $\begin{array}{l}\text { Haresnape \& Wilkinson (1989), } \\
\text { Labuda \& Nuttall (2004, 2008), } \\
\text { de la Fuente et al. (2008a), } \\
\text { Lawrie et al. (2004), Shepherd et } \\
\text { al. (1989), Durden et al. (1993), } \\
\text { Humphery-Smith et al. (1993), } \\
\text { Jupp et al. (1987) }\end{array}$ \\
\hline Ornithodoros parkeri & ASFV ${ }^{1}$, Karshi and Langat virus & $\begin{array}{l}\text { Kleiboeker \& Scoles (2001), Turell } \\
\text { et al. }(1994,2004)\end{array}$ \\
\hline Ornithodoros porcinus & ASFV & $\begin{array}{l}\text { Kleiboeker et al. (1998), Bastos et } \\
\text { al. (2009) }\end{array}$ \\
\hline $\begin{array}{l}\text { Ornithodoros } \\
\text { puertoricensis }\end{array}$ & $\mathrm{ASFV}^{1}$ & $\begin{array}{l}\text { Endris et al. (1991), Kleiboeker } \\
\text { et al. (1998), Labuda \& Nuttall } \\
\text { (2004), de la Fuente et al. } \\
\text { (2008a) }\end{array}$ \\
\hline Ornithodoros savignyi & $\begin{array}{l}\text { AHF virus, Bluetongue virus }{ }^{1} \text {, } \\
\text { ASFV1 }^{1}\end{array}$ & $\begin{array}{l}\text { Kleiboeker et al. (1998), Charrel } \\
\text { et al. (2007), Bouwknegt et al. } \\
(2010)\end{array}$ \\
\hline Ornithodoros sonrai & $\begin{array}{l}\text { Karshi and Langat virus, } \\
\text { ASFV, Bandia virus }\end{array}$ & $\begin{array}{l}\text { Turell et al. (1994, 2004), Vial et } \\
\text { al. (2007), Labuda \& Nuttall } \\
(2008)\end{array}$ \\
\hline Ornithodoros tadaridae & Estero Real virus & $\begin{array}{l}\text { Málková et al. (1985), Labuda \& } \\
\text { Nuttall (2008) }\end{array}$ \\
\hline \begin{tabular}{|l|} 
Ornithodoros \\
tartakovskyi
\end{tabular} & Karshi and Langat virus & Turell et al. (2004) \\
\hline Ornithodoros tholozani & Karshi and Langat virus & Labuda \& Nuttall (2008) \\
\hline Ornithodoros turicata & ASFV $^{1}$ & $\begin{array}{l}\text { Hess et al. (1987), Kleiboeker et } \\
\text { al. (1998), Labuda \& Nuttall } \\
\text { (2004), de la Fuente et al. } \\
\text { (2008a) }\end{array}$ \\
\hline Otobius lagophilus & Colorado tick fever group & Hoogstraal (1985) \\
\hline
\end{tabular}

Table 2. Viruses transmitted by or associated to soft ticks. AHF, Alkhurma hemorrhagic fever virus; CCHF, Crimean Congo haemorraghic fever; ASFV, African swine fever virus; QYB, Qalyub virus. ${ }^{1}$ Experimental infection; ${ }^{2}$ laboratory transmission; ${ }^{3}$ mechanical transmission. 
The pathogenesis of ASFV in Old World Ornithodoros tick species is characterized by a low infectious dose, lifelong infection, and low mortality until after the first oviposition; by contrast, in New World Ornithodoros ticks species relatively high nymphal mortality has been reported after infection, and infection does not appear to be lifelong, although it is not known whether the reduction in the number of infected ticks with time is due to differential mortality or to loss of infection (Kleiboeker \& Scoles, 2001). In general, Ornithodoros ticks have a long life span, and some species can survive up to 15-20 years in their adult stage. Consequently, ASFV-infected soft tick populations can maintain this virus for years, although they do not seem to play an active role in the spreading of the virus over long distances. Recently, O. erraticus specimens collected from pig farms in Portugal more than five years after the removal of infectious hosts showed the presence of the virus and the experimental transmissibility of these persistent infections, highlighting the epidemiological role of O. erraticus ticks in the persistence of ASFV in the field (Boinas et al., 2011).

The epidemiological role played by soft ticks becomes important when domestic pigs are managed under traditional systems, in which pigs range freely in wild or peridomestic habitats and may enter into contact with ticks. Ticks feed mainly on wild hosts living in burrows and pigs are mostly accidental hosts. The mechanism of ASFV transmission from the sylvatic cycle to domestic pigs is probably through infected ticks feeding on pigs.

ASF affects only porcine species. Wild boars have been shown to be susceptible to ASFV infection in Sardinia (Italy), Spain and Portugal, showing similar clinical signs and casefatality rates. This was also the case for experimentally infected feral pigs in Florida. The transmission of ASFV between the European wild boar and soft ticks is unlikely to occur since wild boars do not live in burrows; however wild boars and feral pigs can transmit the virus directly to domestic swine as well as between themselves. Whether wild boars have a reservoir role and/or could be infected in areas with outbreaks in domestic pigs remains to be elucidated (McVicar et al., 1981; Sánchez-Vizcaíno, 2006). In Africa, it has been observed that ASFV induces an unapparent infection in three species of wild swine (warthogs, bushpigs and red river hogs); however, current evidence suggests an unlikely role for bushpigs in the maintenance and transmission of ASFV, while the role played by the giant forest hog has not yet been clarified (Jori and Bastos, 2009; Ravaomanana et al., 2011).

The disease is currently endemic in many countries of Africa (mainly located south of the Sahara), Sardinia and the Caucasus. In Africa it is maintained by a cycle of infection between wild suidae and soft ticks. ASFV infection is characterized by low levels of virus in host tissues and low or undetectable levels of viraemia, but this is sufficient to infect soft tick vectors and cause subsequent tick transmission to domestic pigs. In Europe, ASF is still endemic in Sardinia, where wild boars seem to be as susceptible as domestic pigs. Previous studies have failed to find ticks from the O. erraticus complex in Sardinia (Encinas-Grandes, pers. com.), but those studies did not rule out the presence of the tick and this aspect deserves further attention. More recently in 2007, ASFV spread to Georgia and later to the Trans-Caucasic countries and the Russian Federation, with devastating effects on pig production (Rowlands et al., 2008). The origin of the outbreak is more probably related to entry through international ports or airports through swine fed with garbage containing ASFV-contaminated wastes. The vector competence of ticks for the ASFV currently circulating in the Caucasus is unknown; however the presence of ticks of the O. erraticus group has been reported in the Caucasus (Table 1). 
Currently, the eradication of ASF from endemic areas is very difficult to achieve because there is no effective vaccine or treatment and the virus can be transmitted by many other routes besides tick bites. Thus, the prevention of the introduction of the virus into new areas and control of tick populations are of great importance to avoid the risk of ASF spreading from infected areas into new ones, as could be the case of virus spread throughout Europe from the Caucasus. Recommendations based on the development of an integrated strategy involving trans-Caucasus countries, the Russian Federation, and the European Union should facilitate the trans-boundary control of ASF (Wieland et al., 2011). The EFSA Panel on Animal Health and Welfare (EFSA 2010a, b, c) offers more detailed information about ASF, ASFV and its vectors in Europe, also presenting several recommendations regarding the ASFV vectorial ability of soft ticks for effective disease management.

\subsection{Other soft tick transmitted viruses}

West Nile virus has been isolated from O. moubata ticks, suggesting that ticks can become infected after feeding on viremic hosts (Lawrie et al., 2004). The tick maintains the infection through moulting, and can transmit the virus to laboratory rodents during a second blood meal (Lawrie et al., 2004). These findings suggest a potential role for O. moubata as a reservoir and vector of West Nile virus.

Ornithodoros ticks can also become infected with the encephalitis-producing Karshi and Langat virus group, and hence they can transmit it vertically and horizontally. These viruses have been passed in O. moubata cell lines without changing their biological properties (BellSakyi et al., 2009). Taken together, these observations suggest a potential role for O. moubata as a vector of this virus group.

Indirect evidence has shown the presence of RNA from flaviviruses such as Alkhurma virus in O. savignyi (Charrel et al., 2007), suggesting the possibility of viral replication in this argasid and, consequently, its potential role as a vector. This possibility should be further investigated.

O. savignyi ticks can also become infected with serotype 8 of the bluetongue virus (BTV8), and this infection has been shown to be transmitted transovarially, suggesting that this soft tick could be a potential vector for bluetongue virus. Although soft ticks do not occur on livestock in Europe, they could play a role in the introduction of bluetongue virus in this region (Bouwknegt et al., 2010).

Several studies have been carried out to determine the presence of Crimean Congo Hemorrhagic Fever (CCHF), hepatitis B and HIV-1 viruses in O. moubata, with the conclusion that only the hepatitis B virus could be transmitted mechanically to man by this argasid (Jupp et al., 1987). Later, Shepherd et al. (1989) and Durden et al. (1993) confirmed the absence of laboratory transmission of CCHF virus by Argas walkerae, O. sonrai, O. porcinus and O. savignyi. Humphery-Smith et al. (1993) confirmed the absence of HIV-1 transmission by $O$. moubata, although these authors commented that this may not be the situation under field conditions.

The absence of CCFH virus in O. moubata is in accordance with the notion that the CCFH virus is not associated with argasids. However, two exceptional reports exist of the isolation of 
$\mathrm{CCHF}$ virus from argasids, although the information should be regarded with caution. The first one reports the isolation of the virus from an O. lahorensis larva in Iran (Sureau et al. 1980), although this was not confirmed later; the second report describes the isolation of the virus from A. persicus in Uzbeck (Rusia) (Hoogstraal, 1985). Recently, in CCHF endemic areas of Iran $O$. lahorensis and $A$. reflexus ticks collected from infected and non-infected hosts have been found to be infected with the CCHF virus (Telmadarraiy et al., 2010; Tahmasebi et al., 2010). Moreover, in these areas antibodies to the $\mathrm{CCHF}$ virus have been found in domestic and wild animals and in birds, in which the virus can replicate and, consequently, be spread over long distances (Chevalier et al., 2004). Although it has not been evaluated whether O. lahorensis or A. reflexus can transmit the CCHF virus, the above data suggest that these ticks could be real vectors of this virus, reflecting the broad range of animal species that can act as reservoirs for the CCHF virus, and also the varied range of potential animals acting as tick hosts. Should this be confirmed, the real field situation for CCHF could be unexpectedly worrying.

Some arboviruses have been identified in Argas spp. ticks such as Kao Shuan, Pathum Thani and Nyamanini viruses (Hoogstraal et al., 1975), the West Nile virus (WNV) (Mumcuoglu et al., 2005), Issyk-Kul Fever virus (Gavrilovskaya, 2001), and Mono Lake virus (Labuda \& Nuttall, 2008). Since the main hosts of Argas spp. ticks are birds, more research is necessary to know the role of tick-infested migratory birds as distributors of emerging arthropodborne viral diseases worldwide.

About one fourth of the last pandemics were originated by the spread of vector-borne pathogens (Alcaide et al., 2009). Emerging pathogens are frequently RNA viruses with a broad host range, and tick-borne viruses are found in all the RNA virus families (Labuda and Nuttall, 2004; Reperant, 2010). Since these new pathogens can emerge either through introduction into a new population or when the interaction with the vector changes, it is very important to identify the new vectors and reservoirs of such pathogens.

\subsection{Bacteria causing relapsing fevers}

The most frequent bacterial disease transmitted by soft ticks is human recurrent (relapsing) fever, causing high fever in patients that abates and then recurs, giving the disease its name. Other argasid-borne bacteria causing disease in animals are less frequent, or simply underreported.

Human relapsing fever is an arthropod-borne infection caused by Borrelia spp. spirochetes, whose reservoir hosts are usually wild rodents (Cutler, 2006, 2009). There are two types of human relapsing fever: the endemic or tick-borne (TBRF) type (Calia \& Calia, 2000; Dworkin et al., 2002, 2009), caused by several Borrelia species and transmitted mainly -but not onlyby ticks of the genus Ornithodoros (Table 3), and the epidemic or louse-borne type, caused by Borrelia recurrentis and transmitted by the human body louse Pediculus humanus; this type is more severe than the tick-borne variety.

Ornithodoros spp. ticks act not only as vectors but also as reservoirs of relapsing fever spirochetes, which seem to be quite vector-specific without crossed infections (Shanbaky \& Helmy, 2000). Each Borrelia species responsible is identified closely with its tick vector and such species share parallel nomenclature; for example, Borrelia hermsii is the agent transmitted by Ornithodoros hermsii. Vertebrates and humans become infected during a tick blood meal through contamination of the feeding site by salivary and/or coxal secretions of the tick (Parola \& Raoult, 2001). Also, transplacental transmission has been reported (Cutler, 2006). 


\begin{tabular}{|c|c|c|c|}
\hline \multicolumn{4}{|c|}{ Soft tick-transmitted Borrelia species causing disease in humans } \\
\hline Soft tick species & Borrelia species & Disease & References \\
\hline Argas africolumbae & Borrelia anserina & TBRF & Gothe et al. (1981) \\
\hline Argas persicus & Borrelia anserina & TBRF & Gothe et al. (1981) \\
\hline Carios kelleyi & Borrelia johnsoni & TBRF & Schwan et al. (2009) \\
\hline Ornithodoros asperus & $\begin{array}{l}\text { Borrelia caucasica, } \\
\text { Borrelia microti, } \\
\text { Borrelia baltazardi }\end{array}$ & TBRF & $\begin{array}{l}\text { Assous \& Wilamowski (2009), } \\
\text { Parola \& Raoult (2001) }\end{array}$ \\
\hline Ornithodoros erraticus & $\begin{array}{l}\text { Borrelia microti, } \\
\text { Borrelia hispanica, } \\
\text { Borrelia crocidurae }\end{array}$ & TBRF & $\begin{array}{l}\text { Gaber et al. (1984), Anda et al. } \\
\text { (1996), Masoumi et al. (2009), } \\
\text { Cutler (2009) }\end{array}$ \\
\hline Ornithodoros graingeri & Borrellia graingeri & & Parola \& Raoult. (2001) \\
\hline Ornithodoros hermsi & Borrelia hermsi & TBRF & $\begin{array}{l}\text { Dana (2009), Schwan et al. } \\
\text { (2007) }\end{array}$ \\
\hline Ornithodoros moubata & Borrelia duttoni & TBRF & $\begin{array}{l}\text { Cutler (2006), Mans et al. } \\
\text { (2008a) }\end{array}$ \\
\hline Ornithodoros parkeri & Borrelia parkeri & TBRF & $\begin{array}{l}\text { Dana (2009), Dworkin et al. } \\
\text { (2002) }\end{array}$ \\
\hline Ornithodoros porcinus & Borrelia duttoni & TBRF & $\begin{array}{l}\text { Mitani et al. (2004), Cutler } \\
(2006)\end{array}$ \\
\hline Ornithodoros rudis & Borrelia venezuelensis & TBRF & Rebaudet \& Parola (2006) \\
\hline Ornithodoros savignyi & Borrelia crocidurae & TBRF & $\begin{array}{l}\text { Gaber et al. (1984), Helmy } \\
(2000), \text { Shanbaky \& Helmy } \\
(2000)\end{array}$ \\
\hline Ornithodoros sonrai & Borrelia crocidurae & TBRF & Vial et al. (2006) \\
\hline Ornithodoros talaje & Borrelia mazzottii & TBRF & $\begin{array}{l}\text { Davis (1956), Rebaudet \& } \\
\text { Parola (2006) }\end{array}$ \\
\hline $\begin{array}{l}\text { Ornithodoros } \\
\text { tartakovskyi }\end{array}$ & Borrelia latyschewii & TBRF & $\begin{array}{l}\text { Parola \& Raoult (2001), } \\
\text { Rebaudet \& Parola (2006) }\end{array}$ \\
\hline Ornithodoros tholozani & Borrelia persica & TBRF & $\begin{array}{l}\text { Sidi et al. (2005), Assous \& } \\
\text { Wilamowski (2009), } \\
\text { Moemenbellah-Fard et al. } \\
\text { (2009), Masoumi et al. (2009) }\end{array}$ \\
\hline Ornithodoros turicata & Borrelia turicatae & TBRF & Dana (2009) \\
\hline Ornithodoros zumpti & Borrelia tillae & & Rebaudet \& Parola (2006) \\
\hline \multicolumn{4}{|c|}{ Soft tick-transmitted Borrelia species causing disease in animals } \\
\hline Species & Borrelia species & Disease & References \\
\hline Argas spp. & Borrelia anserina & $\begin{array}{l}\text { Avian } \\
\text { spirochetosis }\end{array}$ & Barbour \& Hayes (1986) \\
\hline Argas miniatus & Borrelia anserina ${ }^{1}$ & \begin{tabular}{|l} 
Avian \\
spirochetosis
\end{tabular} & Lisbôa et al. (2009) \\
\hline Ornithodoros coriaceus & Borrelia coraciae & $\begin{array}{l}\text { Bovine } \\
\text { epizootic } \\
\text { abortion }\end{array}$ & $\begin{array}{l}\text { Hendson \& Lane (2000), } \\
\text { Barbour \& Hayes (1986), } \\
\text { Teglas et al. (2006), Chen et al. } \\
(2007)\end{array}$ \\
\hline
\end{tabular}

Table 3. Bacteria transmitted by soft ticks. TBRF, tick-borne relapsing fever. ${ }^{1}$ Experimental transmission. 
At present, TBRF can be considered a zoonotic disease since endemic foci in humans have been detected in zones with high prevalences in animals and high infection rates in ticks (McCall et al., 2007). TBRF is characterized by episodes of recurrent fever and other nonspecific symptoms, such as headache and myalgia. If not treated with antibiotics it can be fatal. In Tanzania, TBRF caused by B. duttoni is endemic. The infection primarily occurs in children and pregnant women, and is associated with foetal loss and neonatal deaths. Perinatal death ratios of 436/1000 have been reported from disease-endemic regions of the country (Cutler, 2006). The laboratory diagnosis of TBRF is done by detecting the spirochetes in human peripheral blood or, better, by flagelin gene PCR amplification and sequencing (Kawabata et al., 2006; Assous \& Wilamowski, 2009). This method can be applied to any infection by Borrelia spp. spirochetes and allows the specific identification of the etiologic agent. Currently, any Borrelia species could represent a health risk for any country, since an exotic pathogen may be introduced into that country by infected people coming from endemic areas. TBRF is considered an emerging disease and it should be kept in mind by health-care providers, especially when dealing with travellers showing symptoms such as fever and in whom malaria is not detected.

More studies are necessary to determine the geographical distribution of Borrelia-infected soft ticks, the prevalences of tick infection, and how these prevalences change, and also to identify any new reservoir.

\subsection{Other pathogens transmitted by soft ticks}

Soft ticks also transmit other pathogens, most of which are important rickettsiae impacting human and animal health. In addition, some protozoan and filarial species may be also transmitted by argasids (Table 4).

Modern molecular biology techniques have enabled the detection of a large number of rickettsial species in argasids. In many cases, the importance of these rickettsiae as pathogens remains to be determined, as does the epidemiological role played by argasid ticks as their vectors and that of migratory birds as spreaders. As already occurs in ixodids, it is anticipated that increasing numbers of new bacterial species will be detected in argasid ticks.

\section{Soft ticks as pathogen vectors in a changing environment}

Climate is an important factor in the geographic distribution of arthropod vectors. Environmental and climatic global change is currently exerting a strong impact on the transmission and distribution of tick-borne pathogens (El Kammah et al., 2007). The effect of climate on infectious diseases is largely determined by the unique transmission cycle of each pathogen. Transmission cycles that require a vector are more susceptible to external environmental influences than diseases which include only the pathogen and host (EstradaPeña, 2009).

Generally, the most significant determinant in the transmission of vector-borne pathogens is the survival rate of the vector involved. Warmer temperatures generally increase the survival and development rates of blood-feeding vectors; however, host availability is more important than climate in determining the abundance and distribution of vector ticks (Patz, et al., 2010). Climatic conditions and the political changes with human biotic, abiotic, and synergistic causal factors mainly affecting agriculture, cover and land properties and their 
use, have a strong effect on the structure of the vegetation, favouring tick ecology (Randolph, 2008, 2010) and, probably, the expansion of tick populations from heavily infested areas of the planet -such as Africa- to nearby places such Europe (Gray et al., 2009) and to more distant areas such Australia, Latin America, and parts of Asia. The increase in tick populations can enhance the contact rates between hosts and ticks.

\begin{tabular}{|c|c|c|c|}
\hline Specie & Pathogen & Disease & References \\
\hline Argas spp. & Aegyptianella pullorum & Aegyptianellosis & El Kammah et al. (2007) \\
\hline Argas arboreus & Wolbachia persica ${ }^{1}$ & & Noda et al. (1997) \\
\hline Argas persicus & $\begin{array}{l}\text { Rahnella aquatilis, } \\
\text { Pseudomonas fluorescens, } \\
\text { Enterobacter cloacae, } \\
\text { Chryseomonas luteola, } \\
\text { Chryseobacterium } \\
\text { meningosepticum } \\
\end{array}$ & & Montasser (2005) \\
\hline Argas vespertilionis & Borrelia burgdorferi & Lyme disease & Hubbard et al. (1998) \\
\hline Carios capensis & $\begin{array}{l}\text { Rickettsia scc3, } \\
\text { Rickettsia hoogstraalii }\end{array}$ & Spotted fever & \begin{tabular}{|l} 
Reeves et al. (2005), \\
Kawabata et al. (2006)
\end{tabular} \\
\hline \multirow{4}{*}{ Carios kelleyi } & Rickettsia spp. $^{2}$ & & Loftis et al. (2005) \\
\hline & \begin{tabular}{|l|} 
Borrelia spp. \\
Borrelia lonestari, \\
Rickettsia felis \\
\end{tabular} & & $\begin{array}{l}\text { Schwan et al. (2009) } \\
\text { Loftis et al. (2005) }\end{array}$ \\
\hline & $\begin{array}{l}\text { Two undescribed } \\
\text { Rickettsia spp. }\end{array}$ & & Reeves et al. (2006) \\
\hline & Bartonella henselae & $\begin{array}{l}\text { Cat scratch } \\
\text { disease }\end{array}$ & Loftis et al. (2005) \\
\hline Carios sawaii & Rickettsia scc3 & Spotted fever & Kawabata et al. (2006) \\
\hline Ornithodoros coriaceus & Deltaproteobacteria & \begin{tabular}{|l|} 
Bovine \\
Epizootic \\
Abortion \\
\end{tabular} & $\begin{array}{l}\text { Teglas et al. (2006), Chen } \\
\text { et al. (2007) }\end{array}$ \\
\hline Ornithodoros erraticus & Babesia meri & & $\begin{array}{l}\text { Gunders \& Hadani } \\
\text { (1973) }\end{array}$ \\
\hline Ornithodoros lahorensis & Coxiella burnetii ${ }^{5}$ & Q-fever & Mishchenko et al. (2010) \\
\hline \multirow{4}{*}{ Ornithodoros moubata } & Rickettsia spp. $^{2}$ & Q-fever & Cutler et al. (2006) \\
\hline & $\begin{array}{l}\text { Proteobacteria simbiont }{ }^{6}, \\
\text { Another specific } \\
\text { simbiont }^{7}\end{array}$ & & Noda et al. (1997) \\
\hline & Babesia equi ${ }^{5}$ & Babesiosis & Battsetseg et al. (2007) \\
\hline & Acanthocheilonema viteae ${ }^{5}$ & Filariasis & Lucius \& Textor (1995) \\
\hline Ornithodoros sonrai & Coxiella burnetii & Q-fever & Mediannikov et al. (2010) \\
\hline $\begin{array}{l}\text { Ornithodoros } \\
\text { tartakowskyi }\end{array}$ & Dipetalonema viteae 5 & Filariasis & Londoño (1976) \\
\hline
\end{tabular}

Table 4. Other bacteria, protozoa and filariae with medical/veterinary interest harboured or transmitted by argasid ticks. ${ }^{1 S y m b i o n t ;}{ }^{2}$ novel rickettsial agent; ${ }^{3}$ closely related to Borrelia turicatae; 4 likely agent; ${ }^{5}$ experimental transmission or infection; ${ }^{6}$ gamma subgroup of proteobacteria symbiont monophyletic group with Coxiella burnetii; ${ }^{7}$ symbiont which form a monophyletic group with Francisella tularensis and Wolbachia persica. NR, not reported. 
Currently, a change is being noted in the epidemiology of tick-borne diseases caused by changes in environmental parameters: i.e., small changes in temperature can account for large variations in the spreading area of infectious diseases. Increasing tick populations can boost contact rates between ticks and pathogens and also contact between ticks and domestic and wild animals, modifying the endemicity of tick-borne diseases with a higher risk of clinical cases (Cumming \& van Vuuren, 2006). Interestingly, an epidemiological heterogeneity of tick-borne infectious diseases with periodic epidemics is being observed; i.e., those of $\mathrm{CCHF}$, which is now appearing with increasing frequency in new areas of Europe. These changes in disease distribution and the emergence of tick borne diseases in unexpected areas may be associated with pathogen dissemination caused, among others, by the movements of livestock, wild animals, and migratory birds.

To date it has been accepted that many of the etiologic agents of these diseases are transmitted exclusively by hard ticks. This specificity seems to be determined by molecular factors involving ticks (i.e., the intracellular process of blood meal digestion in ticks) and pathogens (infection, replication, aggregation), which condition pathogen infection and development in vectors and vertebrates. However, it is tempting to speculate that there could be some pathogens not exclusively transmitted by either hard or soft ticks, since new conditions favouring ticks and pathogen dissemination could provide the opportunity for the establishment of new tick-pathogen interactions. An example supporting such an idea is the association observed between the CCHF virus and the soft tick species referred to above. Evidently, confirmation of this issue will require evidence that well-known soft-tick pathogens can be transmitted by an ixodid species or, conversely, the transmission by argasids of pathogens normally transmitted by species of ixodid ticks. This highlights the need for a systematic surveillance for as yet unknown associations between pathogens and competent vectors and the occurrence of new emerging diseases.

\section{Soft tick location and surveillance}

As mentioned above, each tick species requires optimum environmental conditions and biotopes for its development, which determine their geographic distribution and the pathogens they transmit (Parola \& Raoult, 2001). Accurate knowledge of the distribution of ticks and the monitoring of changes in their distribution are important to define risk areas for tick-borne diseases and to establish adequate measures for tick control and the prevention of tick-borne disease. In this context, continuous tick surveillance emerges as a permanent need.

Direct methods for tick surveillance are based on the capture and identification of specimens, either from the vegetation (dragging method) or from animal hosts in the area sampled. While these procedures are useful for the surveillance of ixodid ticks owing to their exophilous lifestyle and long feeding times, they will not work with argasid ticks because they are endophilous/nidicolous and fast feeders. This means that vegetation dragging and the removal from animals are inefficient as direct methods for argasid surveillance; instead it is necessary to explore all possible tick refuges in the area sampled before such an area can be considered tick-free (Oleaga-Pérez et al., 1990; Vial et al., 2006). Evidently, this is an impractical procedure for large-scale studies. 
These drawbacks have encouraged the development of serological tests (ELISA) as indirect methods for tick surveillance, especially for argasid ticks. Serological methods are based on the detection of specific antibodies against tick salivary proteins in serum samples taken from animal hosts -or humans- living in the area under study. The development of such methods requires the resolution of several issues such as: 1) the host species to be sampled; these are determined first by the host preference of the tick species investigated, and second by factors such as the availability and ease of management of the different animal hosts. Domestic instead of wild animals are preferred. 2) Demonstration that the tick species investigated induces a humoral immune response. 3) Characterization of the response in terms of how many tick bites are necessary to induce detectable antibody levels, and how long antibodies remain at detectable levels after the last tick-host contact. 4) Which antigen should be used and what its sensitivity and specificity are.

Such tests have been developed for O. erraticus in southern Europe and for O. moubata in Africa. In Spain and Portugal, O. erraticus lives in close association with swine on free-range pig farms, where it can transmit TBRF and ASF. Accordingly, elimination of the tick from pig farms would greatly improve the control of such diseases (Oleaga-Pérez et al., 1990; Manzano-Román et al., 2007). As part of an ASF eradication campaign carried out in the 90's in Spain, an ELISA test was developed to detect specific antibodies against O. erraticus in pigs. The authors of the test demonstrated first that $O$. erraticus bites induced detectable humoral responses in pigs, and that after secondary contact antibody levels were detectable for at least 3 months (Canals et al., 1990). Then, the authors analysed the specificity of the antigen used in the test, which was a crude salivary gland extract (SGE) obtained from adult O. erraticus ticks, with a composition similar to that of tick saliva (Baranda et al., 1997). The SGE demonstrated $100 \%$ sensitivity and specificity with sera from experimentally infected pigs (Pérez-Sánchez et al., 1992) and 90\% sensitivity and specificity in field conditions (Oleaga-Pérez et al., 1994). Subsequently the SGE-ELISA test was used to analyse anti-O. erraticus antibodies in more than 19,000 samples of pig sera from 3,478 farms located in 234 townships in the province of Salamanca (Spain). This allowed the identification of the farms infested with the argasid in the province, the establishment of a significant association between the presence of the tick and the persistence of ASF cases on such farms (PérezSánchez et al., 1994), and consequently the application of specific control measures to avoid tick-pig contact on the tick-infested farms. Recently, a similar serological study has been done in Madagascar to look for the presence of anti-O. moubata ticks in domestic pigs and bushpigs, using as antigen an SGE obtained from adult O. moubata in a similar way to that of O. erraticus (Ravaomanana et al., 2011). The absence of anti-tick antibodies and anti-ASFV in bushpigs suggested that the latter are unlikely to play a significant role in the maintenance and transmission of ASFV in Madagascar. In addition, the presence of antibodies against $O$. moubata in domestic pigs suggests that soft ticks may be able to maintain ASFV within a domestic pig cycle in areas of Madagascar where they remain present.

The above indicates that the O. erraticus and O. moubata SGEs are suitable antigens for the serological surveillance of these two ticks by ELISA tests, although SGEs have some drawbacks. Their collection is time-consuming and difficult to standardise, their composition is poorly known and they may contain non-specific antigens, giving rise to unexpected cross-reactivity. The alternative to SGE would be the use of an individual salivary antigen of proven specificity. With this aim, Baranda et al. (2000) purified the four 
main antigens from both the O. erraticus and O. moubata SGE and studied their diagnostic value. Regarding O. moubata, the best candidate for the serodiagnosis of infested animals was its 20A1 antigen. This antigen was later identified as a homologue of the TSGP1 salivary lipocalin of O. savignyi (Mans et al., 2008b; Oleaga et al., 2007). Recently, this O. moubata TSGP1 has been cloned, obtaining the recombinant form (rOmTSGP1), and shown to have a better diagnostic performance (sensitivity and specificity) than SGE (Díaz-Martín et al., 2011), thereby providing a reliable serologic tool for O. moubata surveillance.

Regarding the use of anti-tick ELISA tests for ixodid surveillance, only a few studies have been carried out using similar SGEs as antigens and human sera (Schwartz et al., 1993; Lane et al., 1999; Nebreda et al., 2004). These studies also confirmed the suitability of the method to detect anti-ixodid tick antibodies but found a high degree of cross-reactivity among ixodid species. As in the case of O. moubata, the use of a specific recombinant antigen would probably solve these problems.

\section{Soft tick control}

Tick control is an intrinsically difficult task for a number of reasons: ticks produce abundant progeny (they lay many eggs); they usually have more than one developmental stage in nature, and they often parasitize numerous and diverse hosts. Several methods for tick control have been used but none of them has been efficacious against all ticks and the problems they cause.

Chemical control with acaricides (arsenicals, chlorinated hydrocarbons, organophosphates, carbamates and synthetic pyrethroids) was considered the best method but resistant tick strains to these acaricides have been selected (Foil et al., 2004). Furthermore, acaricides may cause toxicity problems and contamination of the environment and animal products, such as milk and meat (George et al., 2008). In addition, owing to the nidicolous life-style of the argasids, their control through the use of acaricides is very difficult to achieve simply because it is not feasible to ensure that the acaricide will reach all places where the parasites hide (Astigarraga et al., 1995).

The problems associated with acaricides have encouraged the development of alternative methods for tick control, such as anti-tick vaccines or bio-control using entomopathogenic organisms, including bacteria, fungi and nematodes. To date, the only bio-control agents tested against soft ticks have been entomopathogenic fungi (Samish et al., 2008). These have been shown to be effective against many ixodid species in different laboratory and field studies. The most pathogenic species were Beauveria bassiana and Metarhizium anisopliae (Samish et al., 2004; Ostfeld et al., 2006). These two fungal species have received the greatest attention and have been the object of subsequent studies (Fernandes \& Bittencourt, 2008; Polar et al., 2008). However, such studies have been focused almost exclusively on the control of ixodid ticks, and have neglected the control of argasid ticks. One exception is the work by Sewify \& Habib (2001), which studied the pathogenic effect of M. anisopliae on the argasid tick $A$. persicus. These authors sprayed heavily infested poultry houses with a fungal spore suspension and observed that the argasid population disappeared in 3 weeks. More recently, Zabalgogeazcoa et al. (2008) and Herrero et al. (2011) carried out laboratory trials showing that isolates of $B$. bassiana and Tolypocladium cylindrosporum caused up to $70 \%$ mortality in O. erraticus and up to $40 \%$ mortality in O. moubata. These results justify further 
efforts towards the application of entomopathogenic fungal strains as anti-argasid biocontrol agents.

Immunological control using anti-tick vaccines offers an attractive alternative to the use of acaricides. In spite of the research efforts invested in this field over the last two decades, only two recombinant anti-hard tick vaccines against Rhipicephalus (Boophilus) species have become available commercially (de la Fuente et al., 2007; Willadsen, 2008). The application of these vaccines has shown that it is possible to control tick populations through host vaccination. Nevertheless, the progress in vaccine development against other tick species has been disappointing, and this is especially evident in relation to argasid ticks (de la Fuente \& Kocan, 2003; de la Fuente et al., 2008b; Willadsen, 2008). Among other reasons underlying the slow development of new and more effective anti-tick vaccines, the main one is the difficulty involved in identifying tick protective antigens (Willadsen, 2008).

As far as we know, the only attempts to develop anti-argasid vaccines have been those undertaken by our group, which focused on O. erraticus and O. moubata. We found a concealed antigen from the endothelial gut cells of O. erraticus, the so-called Oe45, which induces a protective response in pigs, causing up to $80 \%$ mortality in nymphs and a $50 \%$ reduction in female fecundity (Manzano-Román et al., 2006, 2007). In O. moubata, a salivary anti-haemostatic protein that acts as an antagonist ligand of the host P-selectin molecule has been characterized (García-Varas et al., 2010). This protein, called Om44, does not elicit an immune response in naturally-infected hosts, but when administered as a vaccine in pigs and rabbits it induces a protective immune response that inhibits tick feeding by up to $70 \%$, and the protective response increases with successive infestations. Hence, Om44 is a new example of "silent" salivary antigen according to the new concept introduced for the salivary sialostatin L2 from I. scapularis (Kotsyfakis et al., 2008).

Consequently, the search for and identification of new anti-soft tick protective antigens should continue, and tick saliva could be an important antigen source. As demonstrated with Bm86, tick gut proteins may also provide good candidate protective antigens. It would be desirable that the new antigens were shared between soft and hard ticks, since this would allow the development of universal anti-tick vaccines. In the search for protective antigens, new genomic-based experimental approaches, such as Expression Library Immunization (ELI) and RNA interference-based screening of cDNA libraries, have been developed and successfully applied to Ixodes scapularis and Amblyomma americanum (Almazán et al., 2005, de la Fuente et al., 2010). The results of these studies showed that the use of RNAi gene silencing for the identification of tick protective antigens is a rapid and cost-effective tool for the discovery of candidate vaccine antigens.

\section{Conclusions}

Soft ticks are distributed worldwide and global climatic changes, along with social factors, influence soft-tick habitats and their hosts. These factors hinder the prediction of the argasid and argasid-borne diseases distribution patterns. Also, several factors could influence the vector competence of soft ticks. A serious swine disease transmitted by argasids is African Swine Fever. This disease jumped between continents in the 60's and 70's and recently in the North of Europe, exemplifying the growing possibility that human and animal tick- 
borne infectious diseases can emerge and colonize previously uninfected areas because the potential distribution of the infection is transcontinental.

Endemic zones for a specific tick-borne pathogen may serve as the origin for its epidemiological dissemination towards new environments, and this dissemination would probably require the adaptation of both the pathogen and the new vector to each other, implying some kind of genetic evolution. The recent characterization of non-specific viruses in argasid vectors and all the argasid-associated pathogens mentioned in this review suggest the great potential of argasids for viral and bacterial disease transmission in any part of the world owing to their extensive geographical distribution and their relatively indiscriminate host feeding.

Here, we show that soft-tick surveillance by serological methods and control thought vaccination could be possible and this opens new avenues for the development and advance of new tests and further research on other argasid species. The possibility that argasids might serve as vectors for many more pathogens that expected requires a greater effort in implementing control measures, such as the search for new protective antigens to be included in a broad spectrum anti-tick vaccine as well as specific coordinated and urgent epidemiological and parasite-surveillance programs. Since there is no single ideal solution for the control of ticks, an integrated control approach is probably the most effective. Vector and reservoir surveillance is an important component of such a strategy.

\section{Acknowledgement}

We thank the financial support of the Spanish Ministry of Science and Innovation (Project AGL2010-18164) and the Regional Government of Castilla y León (Spain) (Project CSI062A11-2) that allowed part of this research. We also thank Dr. Agustin Estrada-Peña for his helpful comments and suggestions.

\section{References}

Adeyeye, OA. \& Butler, JF. (1989). Population structure and seasonal intra-burrow movement of Ornithodoros turicata (Acari: Argasidae) in gopher tortoise burrows. Journal of Medical Entomology, Vol. 26, No. 4, (July 1989), pp. 279-283, ISSN 00222585.

Ahmed, J., Alp, H., Aksin, M. \& Seitzer, U. (2007). Current status of ticks in Asia. Parasitology Research, Vol. 101, No. 2, (September 2007), pp. 159-162, ISSN 0932-0113.

Alcaide, M., Rico, C., Ruiz, S., Soriguer, R., Muñoz, J. \& Figuerola, J. (2009). Disentangling vector-borne transmission networks: a universal DNA barcoding method to identify vertebrate hosts from arthropod bloodmeals. Plos One, Vol. 4, No. 9, (September 2009), pp. 1-6, ISSN 1932-6203.

Almazán, C., Blas-Machado, U., Kocan, KM., Yoshioka, JH., Blouin, EF., Mangold, AJ. \& de la Fuente J. (2005). Characterization of three Ixodes scapularis cDNAs protective against tick infestations. Vaccine, Vol. 23, No. 35, (August 2005), pp. 4403-16, ISSN 0264-410X.

Anda, P., Sánchez-Yebra, W., Del Mar Vitutia, M., Pérez Pastrana, E., Rodríguez, I., Miller, NS., Backenson, PB. \& Benach, JL. (1996). A new Borrelia species isolated from 
patients with relapsing fever in Spain. Lancet, Vol. 348, No. 9021, (July 1996), pp. 162-165, ISSN 0140-6736.

Assous, MV. \& Wilamowski, A. (2009). Relapsing fever borreliosis in eurasia--forgotten, but certainly not gone!. Clinical Microbiology and Infection, Vol. 15, No. 5, (May 2009), pp. 407-414, ISSN 1198-743X.

Astigarraga, A., Oleaga-Pérez, A., Pérez-Sánchez, R. \& Encinas-Grandes, A. (1995). A study of the vaccinal value of various extracts of concealed antigens and salivary gland extracts against Ornithodoros erraticus and Ornithodoros moubata. Veterinary Parasitolgy, Vol. 60, No. 1-2, (November 1995), pp. 133-147, ISSN 0304-4017.

Ataliba, AC., Resende, JS., Yoshinari, N. \& Labruna, MB. (2007). Isolation and molecular characterization of a Brazilian strain of Borrelia anserina, the agent of fowl spirochaetosis. Research in Veterinary Science, Vol. 83, No. 2, (October 2007), 145-149, ISSN 0034-5288.

Aydin, L. \& Bakirci, S. (2007). Geographical distribution of ticks in Turkey. Parasitology Research. Vol. 101, No. 2, (September 2007), pp. 163-166, ISSN 0932-0113.

Baranda, JA., Pérez-Sánchez, R. Oleaga-Pérez, A. \& Encinas-Grandes, A. (1997). Antigens of interest for the diagnosis of parasitism in pigs by Ornithodoros erraticus and Ornithodoros moubata. The Journal of Parasitology. Vol. 83, No. 5, (October 1997), pp. 831-838, ISSN 0022-3395.

Baranda, JA., Pérez-Sánchez, R., Oleaga, A., Manzano, R. \& Encinas-Grandes, A. (2000). Purification, N-terminal sequencing and diagnostic value of the major antigens of Ornithodoros erraticus and O. moubata. Veterinary Parasitology, Vol. 87, No. 1-2, (January 2000), pp. 193-206, ISSN 0304-4017.

Barbour, AG. \& Hayes, SF. (1986). Biology of Borrelia species. Microbiol rev, Vol. 50, No. 4 (December 1986) pp. 381-400. ISSN 0146-0749

Barros-Battesti, DM., Landulfo, GA., Onofrio, VC., Faccini, JL., Marcili, A., Nieri-Bastos, FA., Venzal, JM., \& Labruna, MB. (2011). Carios mimon (Acari: Argasidae): description of adults and redescription of larva. Exp Appl Acarol. Vol. 54, No. 1, (May 2011), pp. 93-104, ISSN 0168-8162.

Basto, AP., Nix, RJ., Boinas, F., Mendes, S., Silva, MJ., Cartaxeiro, C., Portugal, RS., Leitão, A., Dixon, LK. \& Martins, C. (2006). Kinetics of African swine fever virus infection in Ornithodoros erraticus ticks. Journal of General Virology. Vol. 87, No. 7, (July 2006), pp. 1863-1871, ISSN 0022-1317.

Bastos, AD., Arnot, LF., Jacquier, MD. \& Maree, S. (2009). A host species-informative internal control for molecular assessment of African swine fever virus infection rates in the African sylvatic cycle Ornithodoros vector. Medical Veterinary Entomology. Vol. 23, No. 4, (December 2009), pp. 399-409, ISSN 0269-283X.

Battsetseg, B., Matsuo, T., Xuan, X., Boldbaatar, D., Chee, SH., Umemiya, R., Sakaguchi, T., Hatta, T., Zhou, J., Verdida, AR., Taylor, D. \& Fujisaki, K. (2007). Babesia parasites develop and are transmitted by the non-vector soft tick Ornithodoros moubata (Acari: Argasidae). Parasitology, Vol. 134, No. 1, (January 2007), pp. 1-8, ISSN 0031-1820.

Bell-Sakyi, L., Růzek, D. \& Gould, EA. (2009). Cell lines from the soft tick Ornithodoros moubata. Experimental and Applied Acarology, Vol. 49, No. 3, (November 2009), pp. 209-219, ISSN 0168-8162.

Belozerov, VN., Van Niekerk, DJ. \& Butler, HJ. (2003). Population structure of Argas arboreus (Acari: Argasidae) ticks associated with seasonally abandoned mixed heronries, 
dominated by cattle egrets (Bubulcus ibis), in South Africa. Onderstepoort Journal of Veterinary Research. Vol. 70, No. 4, (December 2003), pp. 325-30, ISSN 0030-2465.

Bermúdez, SE., Miranda, RJ. \& Smith, D. (2010). Ticks species (Ixodida) in the summit municipal park and adjacent areas, Panama City, Panama. Experimaental Applied Acarology, Vol. 52, No. 4, (December 2010), pp. 439-448, ISSN 0168-8162.

Boinas, FS., Wilson, AJ., Hutchings, GH., Martins, C. \& Dixon, LJ. (2011). The persistence of African swine fever virus in field-infected Ornithodoros erraticus during the ASF endemic period in Portugal. PLoS One. Vol.6, No. 5, ISSN 1932-6203.

Bouwknegt, C., Van Rijn, PA., Schipper, JJ., Hölzel, D., Boonstra, J., Nijhof, AM., Van Rooij, EM. \& Jongejan, F. (2010). Potential role of ticks as vectors of bluetongue virus. Experimental and Applied Acarology, Vol. 52, No. 2, (April 2010), pp. 183-192, ISSN 0168-8162.

Caeiro, V. (1999). General review of tick species present in Portugal. Parassitologia, Vol. 41, No. 1, (September 1999), pp. 11-15, ISSN 0048-2951.

Calia, KE. \& Calia, FM. (2000). Tick borne relapsing fever. In: Tickborne Infectious Diseases: Diagnosis and Management, Burke A. Cunha (Ed.), pp. 169-183, Informa Healthcare, ISBN: 0-8247-0310-3, New York, USA.

Calisher, CH., Schwan, TG., Lazuick, JS., Eads, RB. \& Francy, DB. (1988). Isolation of Mono Lake virus (family Reoviridae, genus Orbivirus, Kemerovo serogroup) from Argas cooleyi (Acari: Argasidae) collected in Colorado. Journal of Medical Entomology Vol. 25, No. 5, (September 1988), pp. 388-390, ISSN 0022-2585.

Canals, A., Oleaga, A., Pérez, R., Domínguez, J., Encinas, A. \& Sánchez-Vizcaíno, JM. (1990) Evaluation of an enzyme-linked immunosorbent assay to detect specific antibodies in pigs infested with the tick Ornithodoros erraticus (Argasidae). Veterinary Parasitology. Vol. 37, No. 2, (October 1990) pp. 145-153, ISSN 0304-4017.

Charrel, RN., Fagbo, S., Moureau, G., Alqahtani, MH., Temmam, S. \& de Lamballerie, X. (2007). Alkhurma hemorrhagic fever virus in Ornithodoros savignyi ticks. Emerging Infectious Diseases, Vol. 13, No. 1, (January 2007), pp. 153-155, ISSN 1080-6040.

Chen, CI., King, DP., Blanchard, MT., Hall, MR., Aldridge, BM., Bowen, L. \& Stott, JL. (2007). Identification of the etiologic agent of epizootic bovine abortion in fieldcollected Ornithodoros coriaceus koch ticks. Veterinary Microbiology, Vol. 120, No. 3-4, (March 2007), pp. 320-7, ISSN 0378-1135.

Chen, Z., Yang, X., Bu, F., Yang, X., Yang, X. \& Liu, J. (2010). Ticks (Acari: Ixodoidea: Argasidae, Ixodidae) of China. Experimental and Applied Acarology, Vol. 51, No. 4, (August 2010), pp. 393-404, ISSN 0168-8162.

Chevalier, V., de la Rocque, S., Baldet, T., Vial, L. \& Roger F. (2004). Epidemiological processes involved in the emergence of vector-borne diseases: West Nile fever, Rift Valley fever, Japanese encephalitis and Crimean-Congo haemorrhagic fever. Revue Scientifique et Technique (International Office of Epizootics). Vol. 23, No. 2, (August 2004), pp. 535-55, ISSN 0253-1933.

Cilek, JE. \& Knapp, FW. (1992). Occurrence of Ornithodoros kelleyi (Acari: Argasidae) in Kentucky. Journal of Medical Entomology, Vol. 29, No. 2, (March 1992), pp. 349-51, ISSN 0022-2585.

Clifford, CM., Hoogstraal, H., Radovsky, FJ., Stiller, D. \& Keirans, JE. (1980). Ornithodoros (alectorobius) amblus (Acarina: Ixodoidea: Argasidae): identity, marine bird and 
human hosts, virus infections, and distribution in Peru. Journal of Parasitology, Vol. 66, No.2, (April 1980), pp. 312-323, ISSN 0022-3395.

Converse, JD., Hoogstraal, H., Moussa, MI., Feare, CJ. \& Kaiser, MN. (1975). Soldado virus (hughes group) from Ornithodoros (alectorobius) capensis (Ixodoidea: Argasidae) infesting sooty tern colonies in the Seychelles, Indian Ocean. American Journal of Tropical Medicine and Hygiene, Vol. 24, No. 6(pt 1), (November 1975), pp. 1010-1018, ISSN 0002-9637.

Cordero del Campillo, M., Castañón Ordóñez, L. \& Reguera Feo, A. (1994). Indice-catálogo de zooparásitos ibéricos. Ediciones Universidad de León. ISBN: 9788477194033, León (Spain).

Cornely, M. \& Schultz, U. (1992). The tick fauna of eastern Germany. Angewandte Parasitologie, Vol. 33, No. 3, (August 1992), pp. 173-183, ISSN 0003-3162.

Cumming, GS. \& Van Vuuren, DP. (2006). Will climate change affect ectoparasite species ranges?. Global Ecology and Biogeography, Vol. 15, No. 5, (September 2006), pp. 486497, ISSN 1466-822X.

Cutler, SJ., Browning, P., \& Scott, JC. (2006). Ornithodoros moubata, a soft tick vector for Rickettsia in east Africa?. Annals of the New York Academy of Sciences. Vol. 1078, (October 2006), pp. 373-377, ISSN 0077-8923.

Cutler, SJ. (2006). Possibilities for relapsing fever re-emergence. Emerging Infectious Diseases. Vol. 12, pp. 369-374, ISSN 1080-6040

Cutler, SJ. (2009). Relapsing fever - a forgotten disease revealed. Journal of Applied Microbiology, Vol. 108, No. 4, (April 2009), pp. 1115-22, ISSN 1364-5072.

Dana, AN. (2009). Diagnosis and treatment of tick infestation and tick-borne diseases with cutaneous manifestations. Dermatologic Therapy, Vol. 22, No.4, (July 2009), pp. 293326, ISSN 1396-0296.

Davis, GE. (1956). A relapsing fever spirochete, Borrelia mazzottii (sp. nov.) from Ornithodoros talaje from Mexico. American Journal of Hygiene, Vol. 63, No. 1, (January 1956), pp. 13-7, ISSN 0096-5294.

De la Fuente, J. \& Kocan, KM. (2003). Advances in the identification and characterization of protective antigens for development of recombinant vaccines against tick infestations. Expert Review of Vaccines. Vol. 2, No. 4, (August 2003), pp. 583-593, ISSN 1476-0584.

De la Fuente, J., Almazán, C., Canales, M., Pérez de la Lastra, JM., Kocan, KM. \& Willadsen, P. (2007). A ten-year review of commercial vaccine performance for control of tick infestations on cattle. Animal Health Research Reviews. Vol. 8, No. 1, (June 2007), pp. 23-28, ISSN 1466-2523.

De la Fuente, J., Estrada-Peña, A., Venzal, JM., Kocan, KM., \& Sonenshine, DE. (2008a). Overview: ticks as vectors of pathogens that cause disease in humans and animals. Frontiers in Bioscience, Vol.1, No. 13, (May 2008), pp. 6938-6946, ISSN 1093-9946

De la Fuente, J., Kocan, KM., Almazán, C. \& Blouin, EF. (2008b). Targeting the tick-pathogen interface for novel control strategies. Frontiers in Bioscience, Vol. 1, No. 13, (May 2008), pp. 6947-6956, ISSN 1093-9946

De la Fuente, J., Manzano-Román, R., Naranjo, V., Kocan, KM., Zivkovic, Z., Blouin, EF., Canales, M., Almazán, C., Galindo, RC., Step, DL. \& Villar, M. (2010). Identification of protective antigens by RNA interference for control of the lone star tick, 
Amblyomma americanum. Vaccine, Vol. 28, No. 7, (February 2010), pp. 1786-1795, ISSN 0264-410X.

Di Iorio, O., Turienzo, P., Nava, S., Mastropaolo, M., Mangold, AJ., Acuña, DG. \& Guglielmone, AA. (2010). Asthenes dorbignyi (Passeriformes: Furnariidae) host of Argas neghmei (Acari: Argasidae). Experimental and Applied Acarology, Vol. 51, No. 4, (August 2010), pp. 419-422, ISSN 0168-8162.

Diaz, JH. (2009). Endemic tickborne infectious diseases in Louisiana and the Gulf South. Journal of the Louisiana State Medical Society, Vol. 161, No. 6, pp. 325-326, ISSN 00246921.

Díaz-Martín, V., Manzano-Román, R., Siles-Lucas, M., Oleaga, A. \& Pérez-Sánchez, R. (2011). Cloning, characterization and diagnostic performance of the salivary lipocalin protein TSGP1 from Ornithodoros moubata. Veterinary Parasitology. Vol. 178, No. 1-2, (May 2011), pp. 163-172, ISSN 0304-4017.

Dikaev, B. (1981). Argasid tick fauna (Argasidae) of the Chechen-Ingush ASSR. Parazitologiia. Vol. 15, No. 1, (January 1981), pp. 76-78, ISSN 0031-1847.

Durden, LA., Logan, TM., Wilson, ML. \& Linthicum, KJ. (1993). Experimental vector incompetence of a soft tick, Ornithodoros sonrai (Acari: Argasidae), for CrimeanCongo hemorrhagic fever virus. Journal of Medical Entomology, Vol. 30, No. 2, (March 1993), pp. 493-496, ISSN 0022-2585

Durden, LA., Merker, S. \& Beati, L. (2008). The tick fauna of Sulawesi, Indonesia (Acari: Ixodoidea: Argasidae and Ixodidae). Experimental and Applied Acarology Vol. 45, No. 1-2, (June 2008), pp. 85-110, ISSN 0168-8162.

Dworkin, MS., Schwan, TG. \& Anderson DE Jr. (2002). Tick-borne relapsing fever in North America. The Medical Clinics of North America, Vol. 86, No. 2, (March 2002), pp. 41733, ISSN 0025-7125

Dworkin, MS., Schwan, TG., Anderson, DE Jr. \& Borchardt, SM. (2008). Tick-borne relapsing fever. Infectious Disease Clinics of North America, Vol. 22, No. 3, (September 2008), pp. 449-68, ISSN 0891-5520.

El Kammah, KM., Oyoun, LM. \& Abdel-Ahafy, S. (2007). Detection of microorganisms in the saliva and midgut smears of different tick species (Acari: Ixodoidea) in Egypt. Journal of the Egyptian Society of Parasitology, Vol. 37, No. 2, (August 2007), pp. 533539, ISSN 0253-5890.

EFSA (2010a). Scientific Opinion on Geographic Distribution of Tick-borne Infections and their Vectors in Europe and the other Regions of the Mediterranean Basin. EFSA Journal, Vol. 8, No. 9, pp. 1723, ISSN 1831-4732.

EFSA (2010b). Scientific Opinion on the Role of Tick Vectors in the Epidemiology of Crimean-Congo Hemorrhagic Fever and African Swine Fever in Eurasia. EFSA Journal, Vol. 8, No. 8, pp. 1703, ISSN 1831-4732.

EFSA (2010c). Scientific Opinion on African Swine Fever. EFSA Journal, Vol. 8, No. 3, pp. 1556, ISSN 1831-4732.

Endris, RG., Keirans, JE., Robbins, RG. \& Hess, WR. (1989). Ornithodoros (Alectorobius) puertoricensis (Acari: Argasidae): redescription by scanning electron microscopy. Journal of Medical Entomology Vol. 26, No. 3, (May 1989), pp. 146-154, ISSN 0022-2585.

Endris, RG., Haslett, TM. \& Hess, WR. (1991). Experimental transmission of African swine fever virus by the tick Ornithodoros (Alectorobius) puertoricensis (Acari: Argasidae). 
Journal of Medical Entomology, Vol. 28, No. 6, (November 1991), pp. 854-858, ISSN 0022-2585.

Endris, RG., \& Hess, WR. (1994). Attempted transovarial and venereal transmission of African swine fever virus by the Iberian soft tick Ornithodoros (Pavlovskyella) marocanus (Acari: Ixodoidea: Argasidae). Journal of Medical Entomology, Vol. 31, No. 3, pp. 373-81, ISSN 0022-2585.

Estrada-Peña, A., Venzal, JM., González-Acuña, D. \& Guglielmone, AA. (2003). Argas (Persicargas) keiransi n. sp. (Acari: Argasidae), a parasite of the Chimango, Milvago c. chimango (Aves: Falconiformes) in Chile. Journal of Medical Entomology Vol. 40, No. 6, (November 2003), pp. 766-769, ISSN 0022-2585.

Estrada-Peña, A., Venzal, JM., González-Acuña, D., Mangold, AJ. \& Guglielmone, AA. (2006). Notes on new world Persicargas ticks (Acari: Argasidae) with description of female Argas (p.) keiransi. Journal of Medical Entomology Vol. 43, No. 5, (September 2006), pp. 801-9, ISSN 0022-2585.

Estrada-Peña, A. (2009). Tick-borne pathogens, transmission rates and climate change. Frontiers in Bioscience, Vol. 1, No. 14, (January 2009), pp. 2674-2687, ISSN 1093-9946.

Estrada-Peña, A., Mangold, AJ., Nava, S., Venzal, JM., Labruna, MB. \& Guglielmone, AA. (2010). A review of the systematics of the tick family argasidae (Ixodida). Acarologia, Vol. 50, No. 3, (September 2010), pp. 317-333, ISSN 0044-586-X.

Failing, RM., Lyon, CB. \& Mckittrick, JE. (1972). The pajaroello tick bite. The frightening folklore and the mild disease. California Medicine, Vol. 116, No. 5, (May 1972), pp. 16-19, ISSN 0008-1264.

Fernandes, EK. \& Bittencourt, VR. (2008). Entomopathogenic fungi against South American tick species. Experimental and Applied Acarology, Vol. 46, No. 1-4, (December 2008), pp. 71-93, ISSN 0168-8162.

Filippova, NA. (1966). Argasid ticks (Argasidae). Fauna SSSR. Paukoobraznye, Vol. 4, No. 3, pp. 255

Foil, LD., Coleman, P., Eisler, M., Fragoso-Sanchez, H., Garcia-Vazquez, Z., Guerrero, FD., Jonsson, NN., Langstaff, IG., Li, AY., Machila, N., Miller, RJ., Morton, J., Pruett, JH. \& Torr, S. (2004). Factors that influence the prevalence of acaricide resistance and tick-borne diseases. Veterinary Parasitology, Vol. 125, No.1-2, (October 2004), pp. 163-181, ISSN 0304-4017.

Gaber, MS., Khalil, GM., Hoogstraal, H. \& Aboul-Nasr, AE. (1984). Borrelia crocidurae localization and transmission in Ornithodoros erraticus and O. savignyi. Parasitology, Vol. 88, No.3, (June 1984), pp. 403-413, ISSN 0031-1820.

García-Varas, S, Manzano-Román, R., Fernández-Soto, P., Encinas-Grandes, A., Oleaga, A. \& Pérez-Sánchez, R. (2010). Purification and characterisation of a p-selectin-binding molecule from the salivary glands of Ornithodoros moubata that induces protective anti-tick immune responses in pigs. International Journal of Parasitology, Vol. 40, No. 3, (March 2010), pp. 313-26, ISSN 0020-7519.

Gavrilovskaya, IN. (2001). Issyk-Kul virus disease, In: The encyclopedia of arthropod-transmitted infections of man and domesticated animals. Cabi Publishing, pp. 231-234, ISBN-13: 978-0851994734, NY.

George, JE., Pound, JM. \& Davey, RB. (2008). Acaricides for controlling ticks on cattle and the problem of acaricides resistance. In: Ticks: biology, disease and control. Alan S. 
Bowman \& Pat Nuttall (Eds.), pp. 408-423, Cambridge University Press, ISBN 9780-521-86761-0, Cambridge, UK.

Ghosh, S., Bansal, GC., Gupta, SC., Ray, D., Khan, MQ., Irshad, H., Shahiduzzaman, M., Seitzer, U. \& Ahmed, JS. (2007). Status of tick distribution in Bangladesh, India and Pakistan. Parasitology Research Vol. 101, No. 2, (September 2007), pp. 207-216, ISSN 0932-0113

Gilot, B. \& Pautou, G. (1982). Evolution of populations of ticks (Ixodidae and Argasidae) in relation to artificialization of the environment in the French Alps. Epidemiologic effects. Acta Tropica, Vol. 39, No. 4, (December 1982), pp. 337-354, ISSN 0001-706X.

González-Acuña, D. \& Guglielmone, AA. (2005). Ticks (Acari: Ixodoidea: Argasidae, Ixodidae) of Chile. Experimental and Applied Acarology Vol. 35, No. 1-2, pp. 147-63, ISSN 0168-8162.

Gothe, R., Buchheim, C. \& Schrecke, W. (1981). Argas (Persicargas) persicus and Argas (Argas) africolumbae as natural vectors of Borrelia anserina and Aegyptianella pullorum in upper Volta. Berliner und Munchener Tierarztliche Wochenschrift, Vol. 94, No. 14, (July 1981), pp. 280-285, ISSN 0005-9366.

Gray, JS., Dautel, H., Estrada-Peña, A., Kahl, O. \& Lindgren, E. (2009). Effects of climate change on ticks and tick-borne diseases in Europe. Interdisciplinary Perspectives on Infectious Diseases, Volume 2009 (2009), Article ID 593232, 12 pages, doi:10.1155/2009/593232.

Groocock, CM., Hess, WR. \& Gladney, WJ. (1980). Experimental transmission of African swine fever virus by Ornithodoros coriaceus, an argasid tick indigenous to the United States. American Journal of Veterinary Research, Vol.41, No. 4, (April 1980), pp. 591594, ISSN 0002-9645.

Guglielmone, AA., Estrada-Peña, A., Keirans, JE. \& Robbins, RG. (2003). Ticks (Acari: Ixodida) of the Neotropical zoogeographic region. Houten Editors, ISBN 9874368284, Atalanta, 2003.

Guglielmone, AA., Robbins, RG., Apanaskevich, DA., Petney, TN., Estrada-Peña, A., Horak, IG., Shao, R. \& Barker, SC. (2010). The Argasidae, Ixodidae and Nuttalliellidae (Acari: Ixodida) of the world: a list of valid species names. Zootaxa, Vol. 2528, pp. 128, ISSN 1175-5326.

Gugushvili, GK. (1972). Hosts of Ornithodoros verrucosus and O. alactagalis ticks in the Georgian SSR. I. Results of the precipitation test. Meditsinskaia parazitologiia $i$ parazitarnye bolezni, Vol. 41, No. 3, (May 1972), pp. 259-264, ISSN 0025-8326.

Gunders, AE. \& Hadani, A. (1973). An argasid tick, Ornithodoros erraticus (Lucas) a natural vector of Nuttalia meri Gunders. Preliminary communication. Zeitschrift für Tropenmedizin und Parasitologie, Vol. 24, No. 4, (December 1973), pp. 536-538, ISSN 0044-359X.

Haresnape, JM. \& Wilkinson, PJ. (1989). A study of African swine fever virus infected ticks (Ornithodoros moubata) collected from three villages in the asf enzootic area of Malawi following an outbreak of the disease in domestic pigs. Epidemiology and Infection, Vol. 102, No. 3, (June 1989), pp. 507-522, ISSN 0950-2688.

Helmy, N. (2000). Seasonal abundance of Ornithodoros (O.) savignyi and prevalence of infection with Borrelia spirochetes in Egypt. Journal of the Egyptian Society of Parasitology, Vol. 30, No. 2, (August 2000), pp. 607-619, ISSN 0253-5890. 
Hendson, M. \& Lane, RS. (2000). Genetic characteristics of Borrelia coriaceae isolates from the soft tick Ornithodoros coriaceus (Acari: Argasidae). Journal of Clinical Microbiology, Vol. 38, No. 7, (July 2000), pp. 2678-2682, ISSN 0095-1137.

Herrero, N., Pérez-Sánchez, R., Oleaga, A., Zabalgogeazcoa, I. (2011). Tick pathogenicity, thermal tolerance and virus infection in Tolypocladium cylindrosporum. Annals of Applied Biology. Doi:10.1111/J.1744-7348.2011.00485.X, ISSN 0003-4746

Hess, WR., Endris, RG., Haslett, TM., Monahan, MJ. \& Mccoy, JP. (1987). Potential arthropod vectors of African swine fever virus in North America and the Caribbean basin. Veterinary Parasitology, Vol. 26, No. 1-2, (December 1987), pp. 145-155, ISSN 0304-4017.

Heyman, P., Cochez, C., Hofhuis, A., Van der Giessen, J., Sprong, H., Porter, SR., Losson, B., Saegerman, C., Donoso-Mantke, O., Niedrig, M. \& Papa, A. (2010). A clear and present danger: tick-borne diseases in Europe. Expert Review of Anti-infective Therapy, Vol. 8, No. 1, (January 2010), pp. 33-50, ISSN 1478-7210.

Hoogstraal, H., Guirgis, SS., Khalil, GM. \& Kaiser, MN. (1975). The subgenus Persicargas (Ixodoidea: Argasidae: Argas). 27. The life cycle of A. (P.) robertsi population samples from Taiwan, Thailand, Indonesia, Australia, and Sri Lanka. The Southeast Asian Journal of Tropical Medicine and Public Health, Vol. 6, No. 4, (December 1975), pp. 532-539, ISSN 0125-1562.

Hoogstraal, H., Wassef, HY., Easton, ER. \& Dixon, JE. (1977). Observations on the subgenus Argas (Ixodoidea: Argasidae: Argas). 12. Argas (A.) africolumbae: variation, bird hosts, and distribution in Kenya, Tanzania, and South and South-West Africa. Journal of Medical Entomology, Vol. 13, No. 4-5, (January 1977), pp. 441-445, ISSN 0022-2585.

Hoogstraal, H., Clifford, CM. \& Keirans, JE. (1979). The Ornithodoros (alectorobius) capensis group (Acarina: Ixodoidea: Argasidae) of the palearctic and oriental regions. O. (A.) coniceps identity, bird and mammal hosts, virus infections, and distribution in Europe, Africa, and Asia. Journal of Parasitology, Vol. 65, No. 3, (June 1979), pp. 395407, ISSN 0022-3395.

Hoogstraal, H. (1985). Argasid and Nuttalliellid ticks as parasites and vectors. Advances in Parasitology, Vol. 24, pp. 135-238, ISSN 0065-308X.

Horak, IG., Mckay, IJ., Henen, BT., Heyne, H., Hofmeyr, MD. \& De Villiers, AL. (2006). Parasites of domestic and wild animals in South Africa. xlvii. Ticks of tortoises and other reptiles. The Onderstepoort Journal of Veterinary Research, Vol. 73, No. 3, (September 2006), pp. 215-227, ISSN 0030-2465.

Howell, CJ. (1966). Studies on karyotypes of South African argasidae. I. Ornithodoros savignyi. (Audouin) (1827). The Onderstepoort Journal of Veterinary Research, Vol. 33, No. 1, (June 1966), pp. 93-98, ISSN 0030-2465.

Hubbard, MJ., Baker, AS. \& Cann, KJ. (1998). Distribution of Borrelia burgdorferi s.l. spirochaete DNA in British ticks (Argasidae and Ixodidae) since the 19th century, assessed by PCR. Medical and Veterinary Entomology, Vol. 12, No. 1, (January 1998), pp. 89-97, ISSN 0269-283X

Humphery-Smith, I., Thong, YH., Moorhouse, D., Creevey, C., Gauci, M. \& Stone, B. (1991). Reactions to argasid tick bites by island residents on the Great Barrier Reef. Medical Journal of Australia, Vol. 155, No. 3, (August 1991), pp. 181-186, ISSN 0025-729X. 
Humphery-Smith, I., Donker, G., Turzo, A., Chastel, C. \& Schmidt-Mayerova, H. (1993). Evaluation of mechanical transmission of HIV by the African soft tick, Ornithodoros moubata. AIDS. Vol. 7, No. 3, (March 1993), pp. 341-347, ISSN 0269-9370.

Jaenson, TG., Tälleklint, L., Lundqvist, L., Olsen, B., Chirico, J. \& Mejlon, H. (1994). Geographical distribution, host associations, and vector roles of ticks (Acari: Ixodidae, Argasidae) in Sweden. Journal of Medical Entomology, Vol. 31, No.2, (March 1994), pp. 240-256, ISSN 0022-2585.

Jongejan, F. \& Uilenberg, G. (2004). The global importance of ticks. Parasitology, Vol. 129, No. suppl, pp. s3-s14, ISSN 0031-1820

Jori, F. \& Bastos, AD. (2009). Role of wild suids in the epidemiology of African swine fever. Ecohealth, Vol. 6, No. 2, (June 2009), pp. 296-310, ISSN 1612-9202.

Jupp, PG., Joubert, JJ., Cornel, AJ., Swanevelder, C. \& Prozesky, OW. (1987). An experimental assessment of the tampan tick Ornithodoros moubata as vector of hepatitis B virus. Medical Veterinary Entomology, Vol. 1, No. 4, (October 1987), pp. 361-368, ISSN 0269-283X.

Karbowiak, G. \& Supergan, M. (2007). The new locality of Argas reflexus fabricius, 1794 in Warsaw, Poland. Wiadomosci Parazytologiczne,Vol. 53, No. 2, pp. 143-144, ISSN 00435163.

Kawabata, H., Ando, S., Kishimoto, T., Kurane, I., Takano, A., Nogami, S., Fujita, H., Tsurumi, M., Nakamura, N., Sato, F., Takahashi, M., Ushijima, Y., Fukunaga, M. \& Watanabe, H. (2006). First detection of Rickettsia in soft-bodied ticks associated with seabirds, Japan. Microbiology and Immunology, Vol. 50, No. 5, pp. 403-406, ISSN 0385-5600.

Keirans, JE., Clifford, CM. \& Capriles, JM. (1971). Argas (argas) dulus, new species (Ixodoidea: Argasidae), from nests of the palm chat Dulus dominicus in the Dominican Republic. Journal of Economic Entomology. Vol. 64, No. 6, (November 1971), pp. 1410-1413, ISSN 0022-0493.

Keirans, JE., Radovsky, FJ. \& Clifford, CM. (1973). Argas (argas) monachus, new species (Ixodoidea: Argasidae), from nests of the monk parakeet, Myiopsitta monachus, in Argentina. Journal of Medical Entomology, Vol. 10, No. 5, (November 1973), pp. 511516, ISSN 0022-2585.

Keirans, JE., Clifford, CM. \& Hoogstraal, H. (1984). Ornithodoros (alectorobius) yunkeri, new species (Acari: Ixodoidea: Argasidae), from seabirds and nesting sites in the Galapagos Islands. Journal of Medical Entomology, Vol. 21, No. 3, (May 1984), pp. 344-350, ISSN 0022-2585.

Keirans, JE. \& Durden, LA. (2001). Invasion: exotic ticks (Acari: Argasidae, Ixodidae) imported into the United States. A review and new records. Journal of Medical Entomology, Vol. 38, No. 6, (November 2001), pp. 850-861, ISSN 0022-2585.

Khoury, C., Bianchi, R., Massa, AA., Severini, F. Di Luca, M. \& Toma, L. (2011). A noteworthy record of Ornithodoros (Alectorobius) coniceps (Ixodida: Argasidae) from Central Italy. Experimental and Applied Acarology, Vol 54, No. 2, (June 2011), pp. 205209, ISSN 0168-8162.

Kleiboeker, SB., Burrage, TG., Scoles, GA., Fish, D. \& Rock, DL. (1998). African swine fever virus infection in the argasid host, Ornithodoros porcinus porcinus. Journal of Virology, Vol. 72, No. 3, (March 1998), pp. 1711-1724, ISSN 0022-538X. 
Kleiboeker, SB. \& Scoles, GA. (2001). Pathogenesis of African swine fever virus in Ornithodoros ticks. Animal Health Research Reviews, Vol. 2, No.2, (December 2001), pp. 121-128, ISSN 1466-2523.

Kotsyfakis, M., Anderson, JM., Andersen, JF., Calvo, E., Francischetti, IM., Mather, TN., Valenzuela, JG. \& Ribeiro, JM. (2008). Cutting edge: immunity against a "silent" salivary antigen of the lyme vector Ixodes scapularis impairs its ability to feed. Journal of Immunology, Vol. 81, No. 8, (October 2008), pp. 5209-5212, ISSN 0022-1767.

Labruna, MB., Terassini, FA., Camargo, LM., Brandão, PE., Ribeiro, AF. \& Estrada-Peña, A. (2008). New reports of Antricola guglielmonei and Antricola delacruzi in Brazil, and a description of a new argasid species (Acari). Journal of Parasitology, Vol. 94, No. 4, (August 2008), pp. 788-792, ISSN 0022-3395.

Labruna, MB., Nava, S., Terassini, FA., Onofrio, VC., Barros-Battesti, DM., Camargo, LM. \& Venzal, JM. (2011). Description of adults and nymph, and redescription of the larva, of Ornithodoros marinkellei (Acari: Argasidae), with data on its phylogenetic position. Journal of Parasitology, Vol. 97, No. 2, (April 2011), pp. 207-217, ISSN 0022-3395.

Labuda, M. \& Nuttall, PA. (2004). Tick-borne viruses. Parasitology. Vol. 129, pp. 221-245, ISSN 0031-1820.

Labuda, M. \& Nuttall, PA. (2008). Viruses transmitted by ticks. In: Ticks: biology, disease and control. Alan S. Bowman \& Pat Nuttall (Eds.), pp. 253-280, Cambridge University Press, ISBN 978-0-521-86761-0,Cambridge. UK.

Lane, RS., Moss, RB., Hsu, YP., Wei, T., Mesirow, ML. \& Kuo, MM. (1999). Anti-arthropod saliva antibodies among residents of a community at high risk for Lyme disease in California. The American Journal of Tropical Medicine and Hygiene, Vol. 61, No. 5, (November 1999), pp. 850-859, ISSN 0002-9637.

Lawrie, CH., Uzcátegui, NY., Gould, EA. \& Nuttall, PA. (2004). Ixodid and Argasid tick species and West Nile Virus. Emerging Infectious Diseases, Vol. 10, No. 4, (April 2004), pp. 653-657, ISSN 1080-6040.

Lisbôa, RS., Teixeira, RC., Rangel, CP., Santos, HA., Massard, CL. \& Fonseca, AH. (2009). Avian spirochetosis in chickens following experimental transmission of Borrelia anserina by Argas (Persicargas) miniatus. Avian Diseases, Vol. 53, No. 2, (June 2009), pp. 166-168, ISSN 0005-2086.

Loftis, AD., Gill, JS., Schriefer, ME., Levin, ML., Eremeeva, ME., Gilchrist, MJ. \& Dasch, GA. (2005). Detection of Rickettsia, Borrelia, and Bartonella in Carios kelleyi (Acari: Argasidae). Journal of Medical Entomology, Vol. 42, No. 2, (May 2005), pp. 473-480, ISSSN 0022-2585.

Londoño, I. (1976). Transmission of microfilariae and infective larvae of Dipetalonema viteae (Filarioidea) among vector ticks, Ornithodoros tartakowskyi (Argasidae), and loss of microfilariae in coxal fluid. Journal of Parasitology, Vol. 62, No. 5, (October 1976), pp. 786-788, ISSN 0022-3395.

Lucius, R. \& Textor, G. (1995). Acanthocheilonema viteae: rational design of the life cycle to increase production of parasite material using less experimental animals. Applied Parasitology, Vol. 36, No. 1, (February 1995), pp. 22-33, ISSN 0943-0938.

Málková, D., Holubová, J., Cerný, V., Daniel, M., Fernández, A., de la Cruz, J., Herrera, M. \& Calisher, CH. (1985). Estero real virus: a new virus isolated from argasid ticks Ornithodoros tadaridae in Cuba. Acta Virologica, Vol. 29, No. 3, (May 1985), pp. 247250, ISSN 001-723X. 
Manilla, G. (1990). Ornithodoros (Alectorobius) maritimus (Ixodoidea, Argasidae) a new species in Italy and observations on the coniceps-capensis group. Parassitologia. Vol. 32, No. 2, (August 1990), pp. 265-74, ISSN 0048-2951.

Mans, JB., Gothe, R. \& Neitz, AWH. (2008a). Tick toxins: perspectives on paralysis and other forms of toxicoses caused by ticks. In: Ticks: biology, disease and control. Alan S. Bowman \& Pat Nuttall (Eds.), pp. 92-107, Cambridge University Press, ISBN 978-0521-86761-0, Cambridge, UK.

Mans, B.J., Ribeiro, J.W. \& Andersen, J.A. (2008b). Structure, function and evolution of biogenic amine-binding proteins in soft ticks. Journal of Biological Chemistry, Vol. 283, pp. 18721-18733, ISSN 0021-9258.

Manzano-Román, R., Encinas-Grandes, A \& Pérez-Sánchez, R. (2006). Antigens from the midgut membranes of Ornithodoros erraticus induce lethal anti-tick immune responses in pigs and mice. Veterinary Parasitology, Vol. 135, No. 1, (January 2006), pp. 65-79, ISSN 0304-4017.

Manzano-Román, R., García-Varas, S., Encinas-Grandes, A. \& Pérez-Sánchez, R. (2007). Purification and characterization of a 45-kda concealed antigen from the midgut membranes of Ornithodoros erraticus that induces lethal anti-tick immune responses in pigs. Veterinary Parasitology. Vol. 145, No. 3-4, (April 2007), pp. 314-325, ISSN 0304-4017.

Martins, JR., Doyle, RL., Barros-Battesti, DM., Onofrio, VC. \& Guglielmone, AA. (2011). Occurrence of Ornithodoros brasiliensis Aragão (Acari: Argasidae) in São Francisco de Paula, RS, Southern Brazil. Neotropical Entomology, Vol. 40, No. 1 (February 2011), pp. 143-144, ISSN 1519-566X.

Maruashvili, GM. (1965). Studies on natural foci of some diseases in Georgia, USSR. In: Studies on natural foci of some diseases in Georgia, USSR, pp. 469-475, ISBN 19651000816.

Masoumi, Asl H., Goya, MM., Vatandoost, H., Zahraei, SM., Mafi, M., Asmar, M., Piazak, N. \& Aghighi, Z. (2009). The epidemiology of tick-borne relapsing fever in Iran during 1997-2006. Travel Medicine and Infectious Disease, Vol. 7, No. 3, (May 2009), pp. 160 164, ISSN 1477-8939

McCall, PJ., Hume, JC., Motshegwa, K., Pignatelli, P., Talbert, A. \& Kisinza, W. (2007). Does tick-borne relapsing fever have an animal reservoir in East Africa?. Vector Borne and Zoonotic Diseases, Vol. 7, No. 4, (September 2007), pp. 659-666, ISSN 1530-3667.

McVicar, JW., Mebus, CA., Becker, HN., Belden, RC. \& Gibbs, EP. (1981). Induced African swine fever in feral pigs. Journal of the American Veterinary Medical Association, Vol. 179, No. 5, (September 1981), pp. 441-446, ISSN 0003-1488.

Mediannikov, O., Fenollar, F., Socolovschi, C., Diatta, G., Bassene, H., Molez, JF., Sokhna, C., Trape, JF. \& Raoult, D. (2010). Coxiella burnetii in humans and ticks in rural Senegal. PloS Neglected Tropical Diseases, Vol. 4, No. 4, (April 2010), pp. 654, ISSN 1935-2727.

Miller, BR., Loomis, R., Dejean, A. \& Hoogstraal, H. (1985). Experimental studies on the replication and dissemination of qalyub virus (Bunyaviridae: Nairovirus) in the putative tick vector, Ornithodoros (Pavlovskyella) erraticus. The American Journal of Tropical Medicine and Hygiene Vol. 34, No.1, (January 1985), pp. 180-187, ISSN 00029637. 
Mishchenko, OA., Tsvetkova, SM., Borisevich, SV. \& Grabarev, PA. (2010). Experimental study of relations of the argasid ticks Alveonasus lahorensis with Coxiella burneti. Meditsinskaia parazitologiia i parazitarnye bolezni, Vol. 2, pp. 40-42, ISSN 0025-8326.

Mitani, H., Talbert, A. \& Fukunaga, M. (2004). New world relapsing fever Borrelia found in Ornithodoros porcinus ticks in central Tanzania. Microbiology and Immunology, Vol. 48, No. 7, pp. 501-505, ISSN 0385-5600.

Moemenbellah-Fard, MD., Benafshi, O., Rafinejad, J. \& Ashraf, H. (2009). Tick-borne relapsing fever in a new highland endemic focus of western Iran. Annals of Tropical Medicine and Parasitology Vol. 103, No. 6, (September 2009), pp. 529-537, ISSN 00034983.

Montasser, AA. (2005). Gram-negative bacteria from the camel tick Hyalomma dromedarii (Ixodidae) and the chicken tick Argas persicus (Argasidae) and their antibiotic sensitivities. Journal of the Egyptian Society of Parasitology, Vol. 35, No. 1, (April 2005), pp. 95-106, ISSN 0253-5890.

Mumcuoglu, KY., Banet-Noach, C., Malkinson, M., Shalom, U. \& Galun, R. (2005). Argasid ticks as possible vectors of west Nile virus in Israel. Vector Borne Zoonotic Diseases. Vol. 5, No. 1, pp. 65-71, ISSN 1530-3667.

Nava, S., Caparrós, JA., Mangold, AJ. \& Guglielmone, AA. (2006). Ticks (Acari: Ixodida: Argasidae, Ixodidae) infesting humans in northwestern Cordoba province, Argentina. Medicina (B aires). Vol. 66, No. 3, pp. 225-228, ISSN 0025-7680.

Nava, S., Lareschi, M., Rebollo, C., Benítez Usher, C., Beati, L., Robbins, RG., Durden, LA., Mangold, AJ. \& Guglielmone, AA. (2007). The ticks (Acari: Ixodida: Argasidae, Ixodidae) of Paraguay. Annals of Tropical Medicine and Parasitology Vol. 101, No. 3, (April 2007), pp. 255-70, ISSN 0003-4983.

Nava, S., Guglielmone, AA. \& Mangold, AJ. (2009a). An overview of systematics and evolution of ticks. Frontiers in Bioscience, Vol. 14, (January 2009), pp. 2857-2877, ISSN 1093-9946.

Nava, S., Mangold, AJ. \& Guglielmone, AA. (2009b). Field and laboratory studies in a neotropical population of the spinose ear tick, Otobius megnini. Medical and Veterinary Entomology, Vol. 23, No. 1, (March 2009), pp. 1-5, ISSN 0269-283X.

Nava, S., Venzal, JM., Terassini, FA., Mangold, AJ., Camargo, LM. \& Labruna, MB. (2010). Description of a new Argasid tick (Acari: Ixodida) from bat caves in Brazilian Amazon. Journal of Parasitology, Vol. 96, No. 6, (December 2010), pp. 1089-1101, ISSN 0022-3395.

Nebreda Mayoral, T., Merino, FJ., Serrano, JL., Fernández-Soto, P., Encinas, A. \& PérezSánchez, R. (2004). Detection of antibodies to tick salivary antigens among patients from a region of Spain. European Journal of Epidemiolgy. Vol. 19,No. 1, pp. 79-83, ISSN 0393-2990.

Need, JT., Dale, WE., Keirans, JE. \& Dasch, GA. (1991). Annotated list of ticks (Acari: Ixodidae, Argasidae) reported in Peru: distribution, hosts, and bibliography. Journal of Medical Entomology, Vol. 28, No. 5, (September 1991), pp. 590-597, ISSN 0022-2585.

Noda, H., Munderloh, UG. \& Kurtti, TJ. (1997). Endosymbionts of ticks and their relationship to Wolbachia spp. and tick-borne pathogens of humans and animals. Applied and Environmental Microbiology,Vol. 63, No. 10, (October 1997), pp. 39263932, ISSN 0099-2240. 
Ntiamoa-Baidu, Y., Carr-Saunders, C., Matthews, BE., Preston, PM. \& Walker, AR. (2004). An updated list of the ticks of Ghana and an assessment of the distribution of the ticks of Ghanaian wild mammals in different vegetation zones. Bulletin of Entomological Research, Vol. 94, No.3, (June 2004), pp. 245-60, ISSN 0007-4853.

Nyangiwe, N., Gummow, B. \& Horak, IG. (2008). The prevalence and distribution of Argas walkerae (Acari: Argasidae) in the eastern region of the eastern cape province, South Africa. Onderstepoort Journal of Veterinary Research, Vol. 75, No. 1, (March 2008), pp. 83-86, ISSN 0030-2465.

Oleaga-Pérez, A., Pérez-Sánchez, R. \& Encinas-Grandes, A. (1990). Distribution and biology of Ornithodoros erraticus in parts of Spain affected by African swine fever. Veterinary Record, Vol. 126, No. 2, (January 1990), pp.32-37, ISSN 0042-4900.

Oleaga-Pérez, A., Pérez-Sánchez, R., Astigarraga, A. \& Encinas-Grandes, A. (1994) Detection of pig farms with Ornithodoros erraticus by pig serology. Elimination of non-specific reactions by carbohydrate epitopes of salivary antigens. Veterinary Parasitology, Vol. 52, No. 1-2, (March 1994), pp. 97-111, ISSN 0304-4017.

Oleaga, A., Escudero-Población, A., Camafeita, E. \& Pérez-Sánchez R. (2007). A proteomic approach to the identification of salivary proteins from the argasid ticks Ornithodoros moubata and Ornithodoros erraticus. Insect Biochemistry and Molecular Biology. Vol. 37, No. 11, (November 2007), pp. 1149-59, ISSN 0965-1748.

Ostfeld, RS., Price, A., Hornbostel, VL. \& Benjamin, AB. (2006). Controlling ticks and tickborne zoonoses with biological and chemical agents. Bioscience. Vol. 5, pp. 383-394, ISSN 0006-3568.

Pantaleoni, RA., Baratti, M., Barraco, L., Contini, C., Cossu, CS., Filippelli, MT., Loru, L. \& Romano, M. (2010). Argas (Persicargas) persicus (Oken, 1818) (Ixodida: Argasidae) in Sicily with considerations about its Italian and West-Mediterranean distribution. Parasite. Vol. 17, No. 4, (December 2010), pp. 349-355, ISSN 1252-607X.

Parola, P. \& Raoult, D. (2001). Ticks and tickborne bacterial disease in humans: an emerging infection threat. Clinical Infectious Disases,Vol. 32, pp. 897-928, ISSN 1058-4838.

Patz, JA., Githeko, AK., Mccarty, JP., Hussein, S., Confalonieri, U. \& de Wet, UN. (2010). Climate change and infectious diseases. Chapter 6. In: Climate change and health. Fact sheet No. 266. http://www.who.int/globalchange/publications/climatechangechap6.pdf

Pérez-Sánchez, R., Oleaga-Pérez, A. \& Encinas-Grandes, A. (1992). Analysis of the specificity of the salivary antigens of Ornithodoros erraticus for the purpose of serological detection of swine farms harbouring the parasite. Parasite Immunology, Vol. 14, No. 2, (March 1992), pp.201-216, ISSN 0141-9838.

Pérez-Sánchez, R., Astigarraga, A., Oleaga-Pérez, A. \& Encinas-Grandes, A. (1994). Relationship between the persistence of African swine fever and the distribution of Ornithodoros erraticus in the province of Salamanca, Spain. Veterinary Record, Vol. 135, No. 9, (August 1994), pp. 207-209, ISSN 0042-4900.

Petney, TN., Andrews, RH., Mcdiarmid, LA. \& Dixon, BR. (2004). Argas persicus sensu stricto does occur in Australia. Parasitology Research, Vol. 93, No.4, (July 2004), pp. 296-299, ISSN 0932-0113.

Peter, RJ., Van den Bossche, P., Penzhorn, BL. \& Sharp, B. (2005). Tick, fly, and mosquito control-lessons from the past, solutions for the future. Veterinary Parasitology, Vol. 132, No. 3, (September 2005), pp. 205-15, ISSN 0304-4017. 
Phiri, BJ., Benschop, J. \& French, NP. (2010). Systematic review of causes and factors associated with morbidity and mortality on smallholder dairy farms in eastern and southern Africa. Preventive Veterinary Medicine, Vol. 94, No. 1-2, (April 2010), p. 1-8, ISSN 0167-5877.

Poggiato, M. (2008). Argas reflexus, the pigeon tick. A case report. Recenti Progressi in Medicina. Vol. 99, No. 4, (April 2008), pp. 204-206, ISSN 2038-1840.

Polar, P., Moore, D., Kairo, MTK. \& Ramsubhag, A. (2008). Topically applied mycoacaricides for the control of cattle ticks: overcoming the challenges. Experimental and Applied Acarology, Vol. 46, pp. 119-148, ISSN 0168-8162.

Rajput, ZI., Hu, SH., Chen, WJ., Arijo, AG. \& Xiao, CW. (2006). Importance of ticks and their chemical and immunological control in livestock. Journal of Zhejiang University Science-B. Vol. 7, No. 11, (November 2006), pp. 912-921, ISSN 1673-1581.

Randolph, SE. (2008). Dynamics of tick-borne disease systems: minor role of recent climate change. Revue Scientifique et Technique (International Office of Epizootics),Vol. 27, No. 2, (August 2008), pp. 367-381, ISSN 0253-1933.

Randolph, SE. (2010). To what extent has climate change contributed to the recent epidemiology of tick-borne diseases?. Veterinary Parasitology, Vol. 167, pp. 92-94, ISSN 0304-4017.

Ravaomanana, J., Jori, F., Vial, L., Pérez-Sánchez, R., Blanco, E., Michaud, V. \& Roger, F. (2011). Assessment of interactions between African swine fever virus, bushpigs (Potamochoerus larvatus), Ornithodoros ticks and domestic pigs in north-western Madagascar. Transboundary and Emerging Diseases, Vol. 58, No. 3, (June 2011), pp. 247-254, ISSN 1865-1674.

Rawlings, JA. (1995). An overview of tick-borne relapsing fever with emphasis on outbreaks in Texas. Texas Medicine Vol. 91, No. 5, (May 1995), pp. 56-59, ISSN 0040-4470

Rebaudet, S. \& Parola, P. (2006). Epidemiology of relapsing fever borreliosis in Europe. FEMS Immunology and Medical Microbiology, Vol. 48, No.1, (October 2006), pp. 11-15, ISSN 0928-8244.

Reeves, WK., Loftis, AD., Priestley, RA., Wills, W., Sanders, F. \& Dasch, GA. (2005). Molecular and biological characterization of a novel coxiella-like agent from Carios capensis. Annals of the New York Academy of Sciences, Vol. 1063, (December 2005), pp. 343-345, ISSN 0077-8923.

Reeves, WK., Loftis, AD., Sanders, F., Spinks, MD., Wills, W., Denison, AM. \& Dasch, GA. (2006). Borrelia, Coxiella, and Rickettsia in Carios capensis (Acari: Argasidae) from a brown pelican (Pelecanus occidentalis) rookery in South Carolina, USA. Experimantal Applied Acarology, Vol. 39, No. 3-4, pp. 321-329, ISSN 0168-8162.

Reperant, LA. (2010). Applying the theory of island biogeography to emerging pathogens: toward predicting the sources of future emerging zoonotic and vector-borne diseases. Vector Borne Zoonotic Diseases. Vol. 10, No. 2, (March 2010), pp. 105-10, ISSN 1530-3667.

Rowlands, RJ., Michaud, V., Heath, L., Hutchings, G., Oura, C., Vosloo, W., Dwarka, R., Onashvili, T. \& Albina, E., Dixon, LK. (2008). African swine fever virus isolate, Georgia. Emerging Infectious Diseases, Vol. 14, No. 12, (December 2008), ISSN 10806040 .

Samish, M., Ginsberg, H. \& Glazer, I. (2004). Biological control of ticks. Parasitology. Vol. 129, pp. 389-403, ISSN 0031-1820. 
Samish, M., Ginsberg, H. \& Glazer, I. (2008). Anti.ticj biological control agents: assessment and future perspectives. In: Ticks: biology, disease and control. Alan S. Bowman \& Pat Nuttall (Eds.), pp. 447-469, Cambridge University Press, ISBN 978-0-521-86761-0, Cambridge, UK.

Sánchez-Vizcaíno, JM. (2006). African Swine Fever. In: Diseases of Swine. 9th edition. Straw, B., Zimmerman, J., D'Allaire, S., Taylor, D. (Eds.), pp. 291-298, Blackwell Publishing Ltd., ISBN: 9780813817033, Oxford, UK.

Schwan, TG., Corwin, MD. \& Brown, SJ. (1992). Argas (argas) monolakensis, new species (Acari: Ixodoidea: Argasidae), a parasite of California gulls on islands in mono lake, California: description, biology, and life cycle. Journal of Medical Entomology, Vol. 29, pp. 78-97, ISSN 0022-2585.

Schwan, TG., Raffel, SJ., Schrumpf, ME. \& Porcella, SF. (2007). Diversity and distribution of Borrelia hermsii. Emerging Infectious Diseases, Vol. 13, No. 3, (March 2007), pp. 436-42, ISSN 1080-6040.

Schwan, TG., Raffel, SJ., Schrumpf, ME., Gill, JS. \& Piesman, J. (2009). Characterization of a novel relapsing fever spirochete in the midgut, coxal fluid, and salivary glands of the bat tick Carios kelleyi. Vector Borne and Zoonotic Diseases, Vol. 9, No. 6, (December 2009), pp. 643-647, ISSN 1530-3667.

Schwartz, BS., Nadelman, RB., Fish, D., Childs, JE., Forseter, G. \& Wormser, GP. (1993). Entomologic and demographic correlates of anti-tick saliva antibody in a prospective study of tick bite subjects in Westchester County, New York. The American Journal of Tropical Medicine and Hygiene, Vol. 48, No. 1, (January 1993), pp. 50-7, ISSN 0002-9637.

Sewify, GH. \& Habib, SM. (2001). Biological control of the tick fowl Argas persicus by the entomopathogenic fungi Beauveria bassiana and Metarhizium anisopliae. Journal of Pest Science. Vol. 74, pp. 121-123, ISSN 1612-4758.

Shanbaky, NM. \& Helmy, N. (2000). First record of natural infection with Borrelia in Ornithodoros (Ornithodoros) savignyi. Reservoir potential and specificity of the tick to Borrelia. Juornal of the Egyptian Society of Parasitology, Vol. 30, No. 3, (December 2000), pp. 765-780, ISSN 0253-5890.

Shepherd, AJ., Swanepoel, R., Cornel, AJ. \& Mathee, O. (1989). Experimental studies on the replication and transmission of crimean-congo hemorrhagic fever virus in some African tick species. American Journal of Tropical Medicine and Hygiene Vol. 40, No. 3, (March 1989), pp. 326-331, ISSN 0002-9637.

Sidi, G., Davidovitch, N., Balicer, RD., Anis, E., Grotto, I. \& Schwartz, E. (2005). Tick-borne relapsing fever in Israel. Emerging Infectious Diseases, Vol. 11, No. 11, (November 2005), pp. 1784-1786, ISSN 1080-6040.

Siuda, K. (1996). Bionomical and ecological characteristic of ticks (Acari: Ixodida) of significant medical importance on the territory of Poland. Roczniki Akademii Medycznej w Bialymstoku. Vol. 41, No. 1, pp. 11-19, ISSN 1427-941X.

Sonenshine, DE. (1992). Biology of ticks Vol. 1. Oxford University Press, ISBN-13: 9780195059106, New York, USA.

Sonenshine, DE., Lane, RS. \& Nicholson, WL. (2002). Ticks (Ixodida). In: Medical and Veterinary Entomology, G. Mullen and L. Durden (Eds). pp. 517-558. Academic Press, ISBN: 978-0-12-372500-4, Boston, USA. 
Steinlein, DB., Durden, LA. \& Cannon, WL. (2001). Tick (Acari) infestations of bats in New Mexico. Journal of Medical Entomology, Vol. 38, No. 4, (July 2001), pp. 609-11, ISSN 0022-2585.

Stott, JL., Osburn, BI. \& Alexander, L. (1985). Ornithodoros coriaceus (Pajaroello tick) as a vector of bluetongue virus. American Journal of Veterinary Research Vol. 46, No. 5, (May 1985), pp. 1197-1199, ISSN 0002-9645.

Sureau, P., klein, JM., Casals, J., Digoutte, JP., Salaun, JJ., Piazak, N. \& Calvo, MA. (1980). Isolement des virus thogoto, wad medani, wanowrie et de la fievre hemorragique de crimée-congo en Iran a partir de tiques dánimaux domestiques. Annales de L'Institut Pasteur, Série Virologie. Vol. 131e, pp. 185-200, ISSN 0924-4204

Tahmasebi, F., Ghiasi, SM., Mostafavi, E., Moradi, M., Piazak, N., Mozafari, A., Haeri, A., Fooks, AR. \& Chinikar, S. (2010). Molecular epidemiology of Crimean- Congo hemorrhagic fever virus genome isolated from ticks of Hamadan province of Iran. Journal of Vector Borne Diseases, Vol. 47, No. 4, (September 2010), pp. 211-216, ISSN 0972-9062.

Teglas, MB., Drazenovich, NL., Stott, J \& Foley, JE. (2006). The geographic distribution of the putative agent of epizootic bovine abortion in the tick vector, Ornithodoros coriaceus. Veterinary Parasitology, Vol. 140, No. 3-4, (September 2006), pp. 327-33, ISSN 03044017.

Telmadarraiy, Z., Ghiasi, SM, Moradi, M., Vatandoost, H., Eshraghian, MR., Faghihi, F., Zarei, Z., Haeri, A. \& Chinikar, S. (2010). A survey of crimean-congo haemorrhagic fever in livestock and ticks in Ardabil province, Iran during 2004-2005. Scandinavian Journal of Infectious Diseases, Vol. 42, No. 2, pp. 137-141, ISSN 0036-5548.

Tizu, T., Schumaker, S. \& Barros, DM. (1995). Life cycle of Ornithodoros (Alectorobius) talaje (Acari: Argasidae) in laboratory. Journal of Medical Entomology, Vol. 32, No. 3, (May 1995), pp. 249-254, ISSN 0022-2585.

Turell, MJ. \& Durden, LA. (1994). Experimental transmission of langat (tick-borne encephalitis virus complex) virus by the soft tick Ornithodoros sonrai (Acari: Argasidae). Journal of Medical Entomology, Vol. 31, No. 1, (January 1994), pp. 148151, ISSN 0022-2585.

Turell, MJ., Mores, CN., Lee, JS., Paragas, JJ., Shermuhemedova, D., Endy, TP. \& Khodjaev, S. (2004). Experimental transmission of karshi and langat (tick-borne encephalitis virus complex) viruses by Ornithodoros ticks (Acari: Argasidae). Journal of Medical Entomology, Vol. 41, No. 5, (September 2004), pp. 973-977, ISSN 0022-2585.

Ushijima, Y., Oliver, JH. Jr, Keirans, JE., Tsurumi, M., Kawabata, H., Watanabe, H. \& Fukunaga, M. (2003). Mitochondrial sequence variation in Carlos capensis (Neumann), a parasite of seabirds, collected on Torishima Island in Japan. Journal of Parasitology, Vol. 89, No. 1, (February 2003), pp. 196-198, ISSN 0022-3395.

Udvardy, MDF. (1975). A classification of the biogeographical provinces of the world. IUCN Occasional Paper no. 18. Morges, Switzerland: IUCN

Venzal, JM. \& Estrada-Peña, A. (2006). Larval feeding performance of two neotropical Ornithodoros ticks (Acari: Argasidae) on reptiles. Experimantal Appleid Acarology, Vol. 39, No. 3-4, pp. 315-20, ISSN 0168-8162.

Venzal, JM., Estrada-Peña, A., Mangold, AJ., González-Acuña, D. \& Guglielmone, AA. (2008). The Ornithodoros (Alectorobius) talaje species group (Acari: Ixodida: Argasidae): description of ornithodoros (Alectorobius) rioplatensis $\mathrm{n}$. $\mathrm{sp}$. from southern 
South America. Journal of Medical Entomology, Vol. 45, No. 5, (September 2008), pp. 832-40, ISSN 0022-2585.

Vermeil, C., Marjolet, M. \& Chastel, C. (1996). Argas et arbovirus. Actualités. Bulletin de la Societé de Pathologie Exotique, Vol. 89, pp. 363-365, ISSN 0037-9085.

Vial, L., Durand, P., Arnathau, C., Halos, L., Diatta, G., Trape, JF. \& Renaud, F. (2006). Molecular divergences of the Ornithodoros sonrai soft tick species, a vector of human relapsing fever in West Africa. Microbes and Infection, Vol. 8, No. 11, (September 2006), pp. 2605-2611, ISSN 1286-4579.

Vial, L., Wieland, B., Jori, F., Etter, E., Dixon, L. \& Roger, F. (2007). African swine fever virus DNA in soft ticks, Senegal. Emerging Infectious Diseases, Vol. 13, No. 12, (December 2007), pp. 1928-1931, ISSN 1080-6040.

Vial, L. (2009). Biological and ecological characteristics of soft ticks (Ixodida: Argasidae) and their impact for predicting tick and associated disease distribution. Parasite, Vol. 16, No. 3, (September 2009), pp. 191-202, ISSN 1252-607X.

Walton, GA. (1951). Ornithodoros savignyi (Audouin) 1826, Argasidae, in the Embu District of Kenya Colony. East African Medical Journal, Vol. 28, No. 4, (April 1951), pp. 189, ISSN 0012 835X.

Whitney, MS., Schwan, TG., Sultemeier, KB., McDonald, PS. \& Brillhart, MN. (2007). Spirochetemia caused by Borrelia turicatae infection in 3 dogs in Texas. Veterinary Clinical Pathology,Vol. 36, No. 2, (June 2007), pp. 212-216, ISSN 0275-6382.

Wieland, B., Dhollander, S., Salman, M. \& Koenen, F. (2011). Qualitative risk assessment in a data-scarce environment: A model to assess the impact of control measures on spread of African Swine Fever. Preventive Veterinary Medicine, Vol. 99, No. 1, (April 2011), pp. 4-14, ISSN 0167-5877.

Willadsen, P. (2008). Antigen cocktails: valid hypothesis or unsubstantiated hope? Trends in Parasitology. Vol. 24 No., 4 (April 2008) pp. 164-167, ISSN 1471-4922.

Yamaguti, N., Clifford, CM. \& Tipton, VJ. (1968). Argas (Argas) japonicus, new species, associated with swallows in Japan and Korea. (Ixodoidea Argasidae). Journal of Medical Entomology, Vol. 5, No. 4, (October 1968), pp. 453-459, ISSN 0022-2585.

Zabalgogeazcoa, I., Oleaga, A \& Pérez-Sánchez, R. (2008). Pathogenicity of endophytic entomopathogenic fungi to Ornithodoros erraticus and Ornithodoros moubata (Acari: Argasidae). Veterinary Parasitology, Vol. 158, No. 4, (December 2008), pp. 336-343, ISSN 0304-4017. 


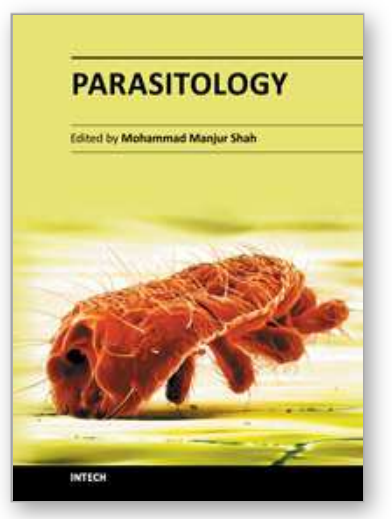

\author{
Parasitology \\ Edited by Dr. Mohammad Manjur Shah
}

ISBN 978-953-51-0149-9

Hard cover, 206 pages

Publisher InTech

Published online 14, March, 2012

Published in print edition March, 2012

Parasitology is an established discipline that covers a wide area of subjects, ranging from the basics (study of life cycle, ecology, epidemiology, taxonomy, biodiversity, etc) to the advanced and applied aspects (human and animal related, although control aspect remains the most important task). There is a great scarcity in the amount of available literature that is freely accessible to anyone interested in the subject. This book was conceptualized with this in mind. The entire book is based on the findings of various studies performed by different authors, comprising reviews and original scientific papers. I hope this book will be helpful to diverse audiences like biologists, zoologists, nematologists, parasitologists, microbiologists, medical doctors, pathologists as well as the molecular biologists, by providing them with a better understanding of the subject.

\title{
How to reference
}

In order to correctly reference this scholarly work, feel free to copy and paste the following:

Raúl Manzano-Román, Verónica Díaz-Martín, José de la Fuente and Ricardo Pérez-Sánchez (2012). Soft Ticks as Pathogen Vectors: Distribution, Surveillance and Control, Parasitology, Dr. Mohammad Manjur Shah (Ed.), ISBN: 978-953-51-0149-9, InTech, Available from: http://www.intechopen.com/books/parasitology/softticks-as-pathogen-vectors-distribution-surveillance-and-control-

\section{INTECH}

open science | open minds

\section{InTech Europe}

University Campus STeP Ri Slavka Krautzeka 83/A 51000 Rijeka, Croatia Phone: +385 (51) 770447 Fax: +385 (51) 686166 www.intechopen.com

\author{
InTech China \\ Unit 405, Office Block, Hotel Equatorial Shanghai \\ No.65, Yan An Road (West), Shanghai, 200040, China \\ 中国上海市延安西路65号上海国际贵都大饭店办公楼405单元 \\ Phone: +86-21-62489820 \\ Fax: +86-21-62489821
}


(C) 2012 The Author(s). Licensee IntechOpen. This is an open access article distributed under the terms of the Creative Commons Attribution 3.0 License, which permits unrestricted use, distribution, and reproduction in any medium, provided the original work is properly cited. 